\title{
Česká muzea, nová média a technologie $\checkmark$ expozicích: Longitudinální studie mezi lety 2015-2020
}

\section{Czech Museums, New Media and Technologies in Exhibitions: Longitudinal Study between 2015-2020}

Abstract: Museums are traditional and collection based cultural institutions. From the very beginning of the 20th century the established approaches in museums have been continuously challenged by social and technological changes. New topics including modernization are newly in the centre of interest. The main method used to examine the current state of using new media in exhibitions and visitor engagement in Czech museums was quantitative research with surveys. With regards to the dynamic development in the area of the research surveys were conducted longitudinally in 2015 and in 2020. This approach helped to capture more complex reality and trends in time. Respondents are museum employees from 358 institutions. The use of new media for museum displays increased significantly, while less than a half of the museums launched an online exhibition project. Almost all museums are offering accompanying programs and more than $80 \%$ also offer game activities. Adoption of new media methods and ideas in Czech museums is gradual but it is increasing. Technically less demanding displays are more frequent, lectures dominate in accompanying programs and games are predominantly non-digital.

Keywords: New media, Museum presentation, Museum modernization, Active visitor, Longitudinal study, Czech museums

\section{Úvod}

Muzea ve společnosti zastávají řadu důležitých rolí a mohou pozitivně ovlivňovat společnost, předávat vědecky aktuální informace a rozvíjet u návštěvníků řadu komplexních dovedností. Ne všechna muzea však dokázala udržet krok s významnými společensko-technologickými změnami, které se v posledních dekádách udály, a projít transformací do společensky důležitých institucí 21 . století. V současnosti jsou muzea pod velkým tlakem a dochází $\mathrm{k}$ přehodnocování jejich rolí a významu ${ }^{1}$, což se odráží i na designu výstav a přístupu $\mathrm{k}$ návštěvníkům.

Článek shrnuje výsledky longitudinální kvantitativní studie mezi lety $2015^{2}$ a 2020, jejímž cílem bylo zjistit stav využívání nových médií a technologií v českých muzeích. Využívat nová média a technologie v muzeích jde jak uvnitř instituce při muzejnické práci ${ }^{3}$, tak $\mathrm{v}$ aktivitách směřujících ven $\mathrm{k}$ návštěvníkům. Pomocí dotazníkového šetření jsem mapovala stav využívání technologií a nových médií ve 3 základních oblastech. V muzejní prezentaci, tedy ve výstavách a expozicích (1 oblast), v práci s návštěvníkem, kdy je návštěvník aktivně zapojován, jak $\mathrm{v}$ expozici, tak $\mathrm{v}$ doprovodných programech (2 oblast) a v online komunikaci $\mathrm{s}$ věřeností a v PR (3 oblast). Vzhledem k množství zjištěných dat se předkládaný text zaměřuje pouze na první dvě oblasti, nebot' spolu úzce souvisí a do velké míry se překrývají. Výsledky ze třetí oblasti, kde jsem se zaměřila zejména na webové

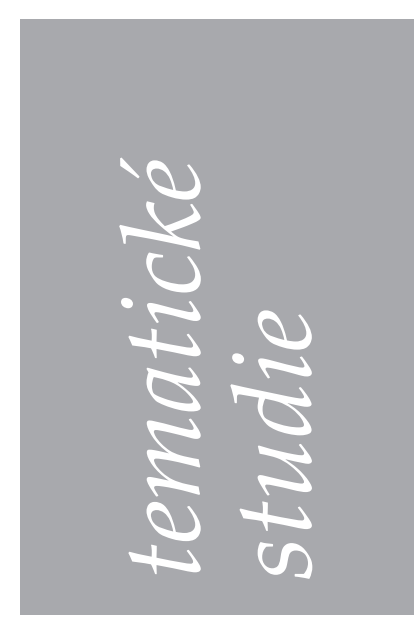

1 Museum Definition, 2020. Museum Definition [online]. 2020. Paris: The International Council of Museums. Dostupné z: https://icom.museum/en/ resources/standards-guidelines/ museum-definition/ 2 Závěry z roku 2015 byly publikovány $v$ čísle 1/2018. 3 JONES, Katherine Burton, 2008. The Transformation of the Digital Museum. In: Museum Informatics: People, Information, and Technology in Museums. 1. vyd. New York: Routledge, s. 9-25. ISBN 0-41580218-0, s. 10-12. 4 SMIRAGLIA, Christina a Lynn BAUM, 2018. Evalution and Audience Research in Museums: Past, Present, Future. In: The State of Museums: Voices from the Field. 1. vyd. United Kingdom: MuseumsEtc, s. 88-119. ISBN 978-1-912528-09-7, s. 90.

Mgr. Nina Wančová, Ph.D. Ústav informačních studií a knihovnictví FF UK nina.wancova@ff.cuni.cz 
5 NEVINS, Elisabeth, 2018. The Past as a Brave Space: Reframing relevance. In: The State of Museums: Voices from the Field. 1. vyd. UK: MuseumsEtc, s. 14-40. ISBN 978-1-912528-09-7, s. $16-19$.

6 BURIÁNKOVÁ, Michaela, Anna KOMÁRKOVÁ

a František ŠEBEK, 2010. Úvod do muzejní praxe: Učební texty základního kurzu

školy muzejní propedeutiky Asociace muzeí a galerií CR.

1. vyd. Praha: Asociace muzeí a galerií Ceské republiky. ISBN 978-80-86611-40-2. 7 BUKAČOVÁ, Jana, Anna KOMÁRKOVÁ a František ŠEBEK, 2014. Muzejní výstavnictví: Učební texty nástavbového kurzu Školy muzejni propedeutiky Asociace muzeí a galerií České republiky.

1. vyd. Praha: Asociace muzeí a galerií České republiky. ISBN 978-80-86611-62-4.

8 JONES, Katherine Burton, 2008. The Transformation of the Digital Museum. In: Museum Informatics: People, Information, and Technology in

Museums. 1. vyd. New York: Routledge, s. 9-25. ISBN 0-415-80218-0.

9 ŠEBEK, František, 2014.

Muzejní výstavnictví a jeho specifika. In: Muzejní výstavnictví: Učební texty nástavbového kurzu Školy muzejní propedeu-

tiky Asociace muzeí a galerii Čské republiky. 1. vyd. Praha: Asociace muzeí a galerii České republiky, s. 9-21. ISBN 978-8086611-62-4, s. 9. 10 SCHALLER, David T., Minda BORUN, Steven ALLISON-BUNNELL a Margaret CHAMBERS, 2007. One Size

Does Not Fit All: Learning Style, Play, and On-line Interactives. In: Museums and the Web 2007: Proceedings [online]. Toronto: Archives \& Museum Informatics. Dostupné z: http://www.archimuse. com/mw2007/papers/schallerl schaller.html

11 DERNIE, David, 2006. Exhibition Design. 1. vyd.

London: Laurence King Publishing. ISBN 978-1-85669$430-8$, s. 6. stránky a sociální sítě, budou zpracovány v samostatném článku, který zahrne i data z výzkumu vlivu pandemie onemocnění COVID-19 na online aktivity muzeí.

V oblasti muzejní prezentace (1. oblast) bylo cílem zjistit, do jaké míry jsou nová média využívána jako řešení exponátů a jak se pracuje s digitalizovanou sbírkou. Typickým prostředkem pro hlubší práci s návštěvníkem (2. oblast) jsou doprovodné aktivity. Cílem výzkumu bylo ověřit předpoklad, že většina muzeí je využívá. V šetření z roku 2020 byla pozornost zaměřena na herní aktivity.

Výzkumné šetření se zaměřilo jen na česká muzea, avšak k analýze závěrů byly využity zahraniční muzejní trendy a zjištovala jsem, v čem se přístup českých institucí liší od těch zahraničních. Stejně jako jsou tvárná samotná nová média, jsou možnosti konkrétních aktivit $\mathrm{v}$ muzeích v podstatě neomezené. Nová média jsou dynamickou oblastí, která se prudce vyvíjí, a proto byl pro výzkumné šetření zvolen longitudinální přístup mapující situaci $\mathrm{v}$ roce 2015 a 2020.

\section{Současný stav poznání a východiska práce}

Tradičně relevantnost muzeí stála na profesionalitě muzejních a muzejně-výzkumných pracovníků, kteří autoritativně prostřednictvím výstav zprostředkovávali návštěvníkům jim nedostupné informace. Úspěšná výstava pak byla ta, která obsahovala kvalitní výběr exponátů, na kterém se shodli odborníci, a názor návštěvníků nebyl podstatný 4 . Proměny ve společnosti, ve způsobech trávení volného času a prudký vývoj v mediálně-technologické sféře způsobily výrazné změny a proměnily jednotlivé činnosti muzeí včetně muzejní prezentace. Muzea sice ztrácí pozici silné informační autority $\mathrm{v}$ dřivějším nadřazeném postavení, nicméně jsou $\mathrm{v}$ procesu ustanovování nové role ${ }^{5}$.

Činnosti, která muzea tradičně vykonávají, lze rozdělit do dvou kategorií - na činnosti důležité pro chod a existenci samotného muzea (činnosti spojené se sbírkou $)^{6}$ a na ty, které směřují ven $\mathrm{k}$ veřejnosti (muzejní prezentace) ${ }^{7}$.

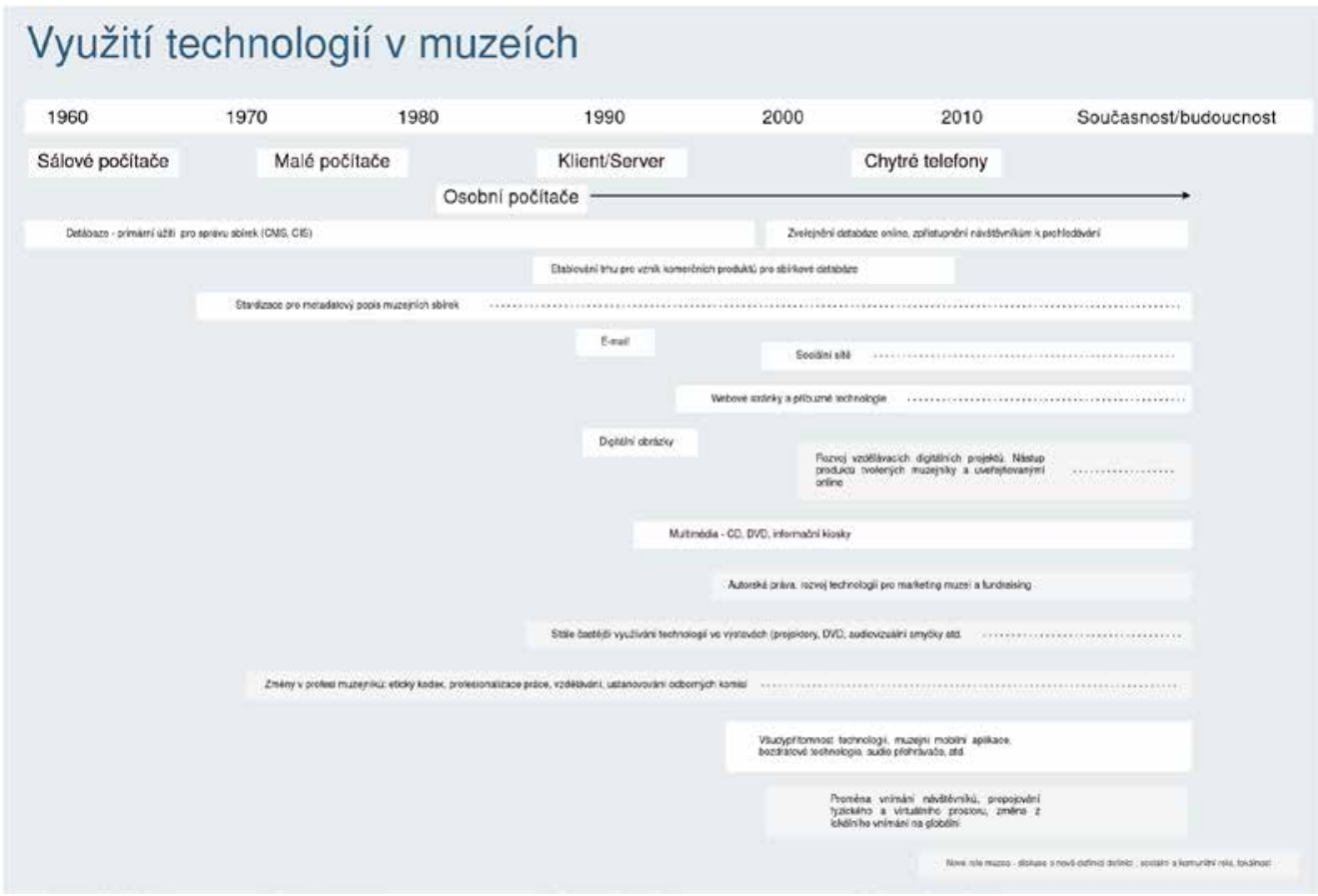

Obr. 1: Pronikání ICT do muzejní praxe

Základ obrázku: Katherine Jones, The Transformation of the Digital Museum, 2008, doplněno autorkou. 
Podmínkou pro využívání nových médií a technologií v druhé skupině aktivit muzeí spojených s prezentací sbírek, vzděláváním a komunikací s veřejností je zejména digitalizace sbírky, znalosti muzejních pracovníků a zkušenosti s informačními a komunikačními technologiemi (ICT) při každodenní práci. Postupnou implementaci technologií do muzeí znázorňuje obr. 1. Tyto podmínky jsou od roku 2000 naplňovány ve stále větším počtu muzeí, čímž rostou možnosti implementace nových médií a technologií právě do oblasti muzejní prezentace ${ }^{8}$.

Muzejní prezentace je pestrá škála aktivit a bez zpř́stupňování sbírek veřejnosti by muzea nenaplňovala své poslání ${ }^{9}$. Do muzejní prezentace řadíme kromě výstav i doprovodné programy, setkání s odborníky, workshopy, komentované prohlídky, kulturní programy, marketing muzeí, virtuální projekty, pracovní listy i publikační činnost. Různorodost umožňuje zaměřovat se na potřeby rozličných cílových skupin a efektivně naplňovat konkrétní cíle ${ }^{10}$. Výstavy a expozice zprostředkovávají dialog mezi autentickými předměty, prostorem, ve kterém jsou instalovány, ${ }^{11}$ a návštěvníkem, který do výstavy fyzicky vstupuje ${ }^{12}$. Ostatní formy obsahu, jakými je zejména text, obrazový doprovodný materiál, informační panely i interaktivní prvky a hry, jsou v českém muzejnictví stále považovány za doplněk ke sbírkovým předmětům ${ }^{13}$.

První a nejdůležitější trend nejen v muzejní prezentaci, ale i v celkové muzejní praxi, je tzv. visitor-centered design, který spočívá v posílení významu návštěvníka oproti dřívějšímu akcentování sbírky. ${ }^{14}$ Zjištování návštěvnických názorů a potřeb není jen otázkou evaluace po návštěvě výstavy, ale stále častěji jsou (potenciální) návštěvníci aktivní součástí přípravy expozic, např. formou uživatelských testování, metody focus groups nebo prototypováni $i^{15}$, což je př́stup, který je v novomediálním prostředí velmi častý ${ }^{16}$.

Druhým trendem je prezentace komplexních témat oproti dřívějšímu prezentování spiše izolovaných předmětů. Do muzejní výstavní řeči se stále častěji zařazují emoce, zprostředkování př́běhů minulosti skrze tzv. malé dějiny, které ukazují (historickou) dobu očima obyčejných lidí17. Snahou je umožnit emocionální propojení návštěvníka s minulostí díky tomu, že návštěvník vystoupí ze své všednosti a ocitá se $\mathrm{v}$ jiném prostředí se specifickou atmosférou ${ }^{18}$. Stírá se také rozdíl mezi minulostí a současností - minulost je reinterpretována a dávána do souvislosti s aktuálními tématy, která ve společnosti rezonuji $1^{19}$.

S komplexními tématy souvisí trètí trend, kterým je vyrovnání významu autentických předmětů s ostatními výstavními prvky. Předměty, které se stanou součástí sbírky, jsou vytrženy ze svého původního prostředí, z doby, kdy byly používány skutečnými lidmi, a jejich význam nemusí být současnému návštěvníkovi zřejmý ${ }^{20}$. Klasická muzejní prezentace stála na logickém uspořádání předmětů především ve vitrínách. Hierarchie exponátů byla jasná - nejdůležitější byly předměty samotné a ostatní prvky byly doplňkové. Dnes jsou klasické prvky, tedy vitríny s předměty, informační panely nebo textové popisky, stále více považovány za pasivní ${ }^{21}$, protože jejich vnímání je založené na absorbování faktů a prostřednictvím doprovodného textu. V aktuálním pojetí muzejní výstavní řeči je patrný překryv s dalšími samostatnými uměleckými disciplínami - performativním či environmentálním uměním, interiérovým, grafickým či světelným designem ${ }^{22}$ a výstavy jsou designovány se snahou vytvořit působivý celek.

Nová média jsou technologicky spjata s počítačem a později s internetem. Počítač je středobodem nových médií; právě skrze něj se uskutečňuje tvorba nového obsahu. Stejně jako jakákoli jiná technologie má i počítač sociální a kulturní rozměr, který ovlivňuje to, jak jej začleňujeme do pracovního i soukromého života ${ }^{23}$. V technologicko-mediální sféře nedochází k nahrazování jednoho média druhým, ale $\mathrm{k}$ synergickému působení, kdy výsledkem je větší technologická rozmanitost v podobě pestrých komunikačních prostředků a jejich kombinací ${ }^{24}$. Nová média
12 MCKENNA-CRESS, Polly a Kamien Janet A., 2013. Creating Exhibitions: Collaboration in the Planning, Development, and Design of Innovative Experiences. 1. vyd. USA: Wiley. ISBN 978-1-11830634-5, s. 5.

13 ŠOBÁÑOVÁ, Petra a Jolana LAŽOVÁ, 2016. Muzeum versus digitální éra. 1. vyd. Olomouc: Univerzita Palackého v Olomouci. ISBN 978-80-2445023-0, s. 32-33.

14 STEHLIKK, Michal, 2010. Nové trendy výstavnictví. In: Úvod do muzejní praxe: Učební texty základního kurzu Školy muzejní propedeutiky Asociace muzeí a galerií Ceské republiky. 1. vyd. Praha: Asociace muzeí a galerií České republiky, s. 295-302. ISBN 978-80-86611-40-2, s. 295. 15 MCKENNA-CRESS,

Polly a Kamien Janet A., 2013. Creating Exhibitions: Collaboration in the Planning, Development, and Design of Innovative Experiences. 1. vyd. USA: Wiley. ISBN 978-1-11830634-5, s. 246-253.

16 SIMON, Nina, 2010. The Participatory Museum. 1. vyd. USA, California: Museum 2.0. ISBN 978-0-615-34650-2, s. $115-120$.

17 SAVENIJE, Geerte $M$. a Pieter de BRUIJN, 2017. Historical empathy in a museum: uniting contextualisation and emotional engagement. International Journal of Heritage Studies [online]. 23(9), 832-845. ISSN 13527258. Dostupné z: doi:10.1080/ 13527258.2017.1339108 18 BUCHTOVÁ, Michaela, 2012. Muzeum jako herní platforma: možnosti použití mobilních telefonù pro infromální učení. Muzeum: Muzejní a vlastivědná práce [online]. 50(2), 3-9. ISSN 1803 0386. Dostupné z: doi:10.2478/ mmvp-2018-0011

19 NEVINS, Elisabeth, 2018. The Past as a Brave Space: Reframing relevance. In: The State of Museums: Voices from the Field. 1. vyd. UK: MuseumsEtc, s. 14-40. ISBN 978-1-912528-09-7, s. $17-20$. 
20 GOINS, Elisabeth, 2011. Museum Games and Narrative: The Way We Tell Stories with Objects. In: Museums at Play: Games, Interaction and Learning. 1. vyd. United Kingdom: MuseumsEtc, s. 500-517. ISBN 978-1-907697$13-5$, s. 504-506.

21 EKRT, Boris, 2017. Výstavní celek muzejního experimentária EperiMus - vývoj od konceptu Přiběh planety země. Muzeum: Muzejní a vlastivědná práce [online]. 55(Zvláštní vydání), 24-27. ISSN 1803-

0386. Dostupné z: doi:10.1515/ mmvp-2017-0032

22 DERNIE, David, 2006.

Exhibition Design. 1. vyd. London: Laurence King Publishing. ISBN 978-1-85669-

430-8, s. 6.

23 PINCH, Trevor J. a Wiebe E. BIJKER, 2012. The Social Construction of Facts and Artifacts: Or How the Sociology of Science and the Sociology of Technology Might Benefit Each Other. In: The Social Construction of

Technological Systems: New

Directions in the Sociology and History of Technology.

Anniversary Edition. USA: MIT Press, s. 11-44. ISBN 978-0-26251-760-7, s. 20-21.

24 JENKINS, Henry, 2008. Convergence Culture:

Where Old and New Media

Collide. 1. vyd. USA: NYU

Press. ISBN 978-0814742952,

s. 16.

25 SEYČKOVÁ, Nina a Marco STELLA, 2014. Evoluce $v$ Hrdličkově muzeu člově-

ka. In: Muzeum a změna

IV. Sborník z mezinárodní muzeologické konference.

Praha: Asociace muzeí a galerií České republiky, s. 267-270.

ISBN 978-80-86611-63-1.

26 MANOVICH, Lev, 2018. Jazyk nových médii. 1. vyd.

Praha: Univerzita Karlova. ISBN 978-80-246-2961-2, s. 150.

27 ABRAHAMSSON, Pekka, Outi SALO, Jussi RONKAINEN a Juhani WARSTA, 2002.

Agile Software Development Methods: Review and Analysis. 1. vyd. Finland: VTT PUBLICATIONS 478. ISBN 95138-6009-4, s. 16-17. považuji na jedné straně za samotné technologické řešení, které stojí na využití počítačù, a souběžně za způsob přemýšlení o obsahu, zvyklosti a očekávání, které se s nimi pojí25.

Jednou ze základních vlastností nových médií je modularita, která umožňuje proměňovat kód, upravovat digitální objekty, skládat je do větších celků nebo je naopak dělit. Komunikační posloupnost spojená s tradičními médii, tedy i s tradičním muzeem, vedla od původce informace $\mathrm{k}$ jejímu př́jemci a nová média tento zažitý koncept narušila ${ }^{26}$. Typickým produktem novomediálního prostředí je software. V současnosti vývojářskému prostředí dominuje agilní metodika, a to v protiváze $\mathrm{k}$ tradičnímu vývoji softwaru, kdy byl do nejmenšího detailu vytvořen celý produkt, který se po vydání zásadně neměnil. Základem agilní metodiky je co nejdříve přijít $s$ alespoň částečně funkčním prototypem a ten dále upravovat, a to díky vstupu uživateli̊ a opakovanému testování27. Příprava muzejní prezentace pak většinou odpovídá tradičnímu způsobu vývoje softwaru ${ }^{28}$. Převedení agilní metodiky do prostředí muzeí by znamenalo, že muzejníci by na přípravě expozic úzce spolupracovali s návštěvníky, kteří se spolupodílejí na rozhodováníi ${ }^{29}$.

Novomediální produkty jsou často označovány jako interaktivní. Pojem interaktivita je problematický, nebot' závisí na míře svobody uživatele a jeho možnostech akce a dávno již přerostl hranice online prostředín $i^{30}$ V sociologii je pojem interakce spojován s mezilidskou komunikací, v novomediální oblasti s komunikací mezi technologií a člověkem, př́padně mezi lidmi skrze technologii ${ }^{31}$. Technologické řešení s sebou nese řadu problémů spojených se způsoby interakce s ICT a nemusí vždy být tím nejlepším řešením. Právě porovnáváním analogového hmatového exponátu a jeho digitální obdoby se zabývala studie zkoumající interakci rodin s exponátem o hudebních rytmech. Analogový exponát dosáhl lepších výsledků, byl využíván déle a měl větší úspěch $u$ rodin $s$ více dětmi ${ }^{32}$. Účelem interaktivních prvků je snaha o zlepšení vzdělávacího potenciálu obsahu, zvýšení motivace k učení a celkové angažovanosti, nebot' je interaktivita spojena s aktivitou a zapojením uživatele ${ }^{33}$.

Neméně důležitým aspektem jako interaktivita je u nových médií multimedialita. Multimedialita je nedílnou součástí fungování i estetiky nových médií a vzhledem $\mathrm{k}$ prostupnosti digitálních technologií do běžných životů lidí je již samozrejmou součástí mediálního prosto$\mathrm{ru}^{34}$. Kombinování různých forem obsahu závisí na fungování samotného počítače, který je multimediálním nástrojem, a to jak svým designem, kdy má v jednu chvíli uživatel $\mathrm{k}$ dispozici řadu ovládacích prvků, médií a nástrojů, tak i možnostmi produkce multimediálního obsahu ${ }^{35}$. Každý multimediální muzejní exponát se skládá z obsahové části a formálního zpracování s využitím konkrétní technologie. Technologické řešení do velké míry ovlivňuje to, jak bude $\mathrm{k}$ exponátu přistupovat návštěvník, a jak na něj exponát bude působit. Využívají se jak zařízení nainstalovaná v muzeu, např. dotykové obrazovky, informační kiosky, projekční zařízení, tak i přenosné technologie. Typickým důvodem pro realizaci multimediálního exponátu je zprostředkovávání informací do větší hloubky v informačních kioscích $^{36}$, audio průvodcích ${ }^{37}$ či mobilních aplikacích $^{38}$. Kromě informační funkce mohou být multimediální technologické exponáty zaměřené i na zprostředkování specifického zážitku a na emoce návštěvníků. Zejména velkoformátové projekční technologie bývají výraznými prezentačními prvky s velkou působností39 na návštěvníka. Samostatnou kapitolou jsou pak multimediální muzejní digitální hry ${ }^{40}$. Pro muzea a muzejní prezentaci jsou nová média využitelná v obou svých rovinách, tedy jak po stránce implementační, tak po stránce ideové. Myšlenky nových médií, jako je zejména spolupráce, tvárnost, iterativní přístup k tvorbě expozic a stírání rozdílu mezi př́jemcem a autorem informací, se manifestují nejen v expozicích samotných, ale $\mathrm{v}$ celkovém fungování instituce. Muzeum, které ve všech rovinách využívá nová média, je pak 
muzeum otevřené, transparentní, dynamické a komplexní.

\section{Longitudinální studie}

V muzejnictví dominuje kvalitativní přístup prostřednictvím případových studií, kdy jsou prezentovány konkrétní př́stupy

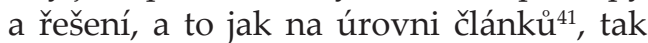
na úrovni $\mathrm{knih}^{42}$. Př́ípadové studie zaměřené na př́klady dobré praxe s jasně vymezeným zaměřením muzea však způsobují zkreslení, kdy vzniká dojem, že prezentované postupy jsou $\mathrm{v}$ dané oblasti standardem. Výzkumný design propojuje zázemí, témata i metodologické postupy muzejnictvíi ${ }^{43}$, informační vědy ${ }^{44}$ a nových médiii ${ }^{45}$. Snahou bylo co nejkomplexněji popsat napříc muzei v České republice (ČR) obraz využivání nových médií a technologií.

\section{Metodologie}

Výzkum je unikátní jak svou metodou, tak výzkumnými otázkami. Využívá právě kvantitativní prrístup typický pro část výzkumu v informační vědě a zahrnuje data z relativně velkého vzorku českých muzeí (celkem 358 institucí). Výzkumné otázky nekopírují žádný z doposud realizovaných výzkumů v ČR, protože se zaměřují na konkrétní technologické a novomediální postupy transformované do muzejní praxe. Zvolenou metodou je dotazníkové kvantitativní šetření pomocí speciálně vytvořených dotazníkủ a statistická analýza dat $v$ jazyce Python. Respondenty výzkumu jsou pracovníci muzeí.

Důležitým rysem výzkumu je jeho časosběrnost. Dotazování proběhlo poprvé v roce 2015 a podruhé o pět let později, na přelomu let 2019/20. Díky porovnání údajů s pětiletým odstupem lze popsat vývoj a zjištěním je dodán další rozměr. Při obou šetřeních byly využity kontakty z veřejně dostupného adresáře muzeí a galerií na stránkách Asociace muzeí a galerií Č ${ }^{46}$.

\section{Výsledky}

\section{Vzorek a všeobecná zjištění}

Po odstranění duplicit $\mathrm{v}$ roce 2015 bylo do vzorku zařazeno 203 muzeí. $\mathrm{V}$ roce
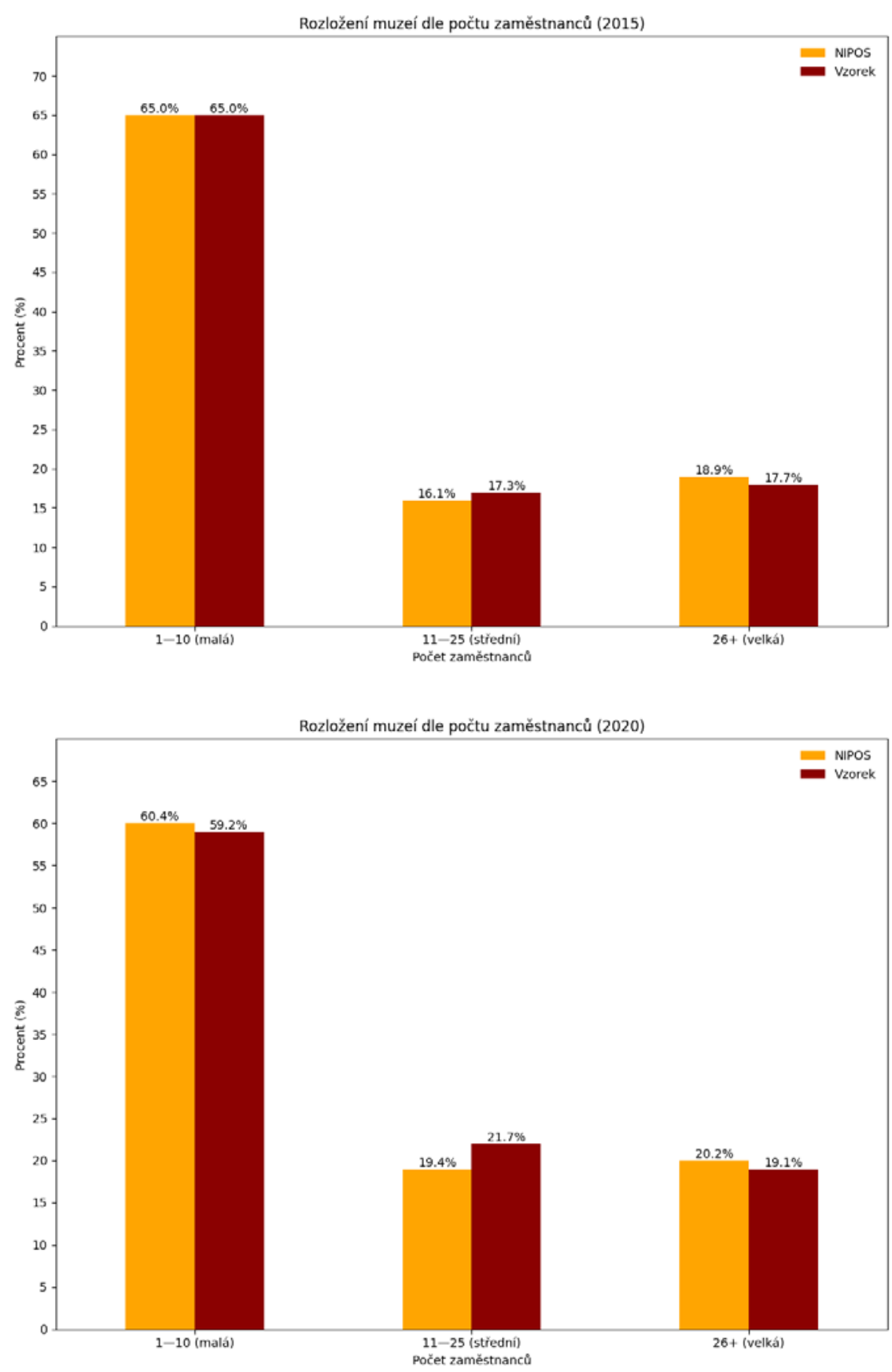

2020 vzorek činil 155 institucí. Kvalita vzorku byla porovnána s oficiálními daty ze statistik kultury, které každoročně provádí Národní informační a poradenské centrum ${ }^{47}$. Pro srovnání jsem vybrala velikost muzea podle počtu zaměstnanců. Ten je zásadní pro možnosti, které vzhledem k modernizaci muzea maji ${ }^{48}$. Schéma vzorku do velké míry odpovídá skutečnému rozložení muzeí a vzorek je tedy dostatečně reprezentativní (graf č. 1 a 2). Muzea navštěvují různé cílové skupiny, z nichž každá má rozličná očekávání, jiné nároky na obsah a nabízené aktivity. Respondenti vybírali z 6 cílových skupin (graf č. 3 a 4). Ve vzorku V2015 respondenti určili jako nejdůležitější cílovou
Graf č. 1: V2015 a jeho porovnání s NIPOS z roku 2015

Graf č. 2: V2020 a jeho porovnání s NIPOS z roku 2019

28 ŠEBEK, František, 2014b. Tvưrčí príprava muzejních expozic a výstav. In: Muzejní výstavnictví: Učební texty nástavbového kurzu Školy muzejní propedeutiky Asociace muzeí a galerií České republiky. 1. vyd. Praha: Asociace muzeí a galerií České republiky, s. 22-43. ISBN 978-80-86611$62-4$, s. 29 

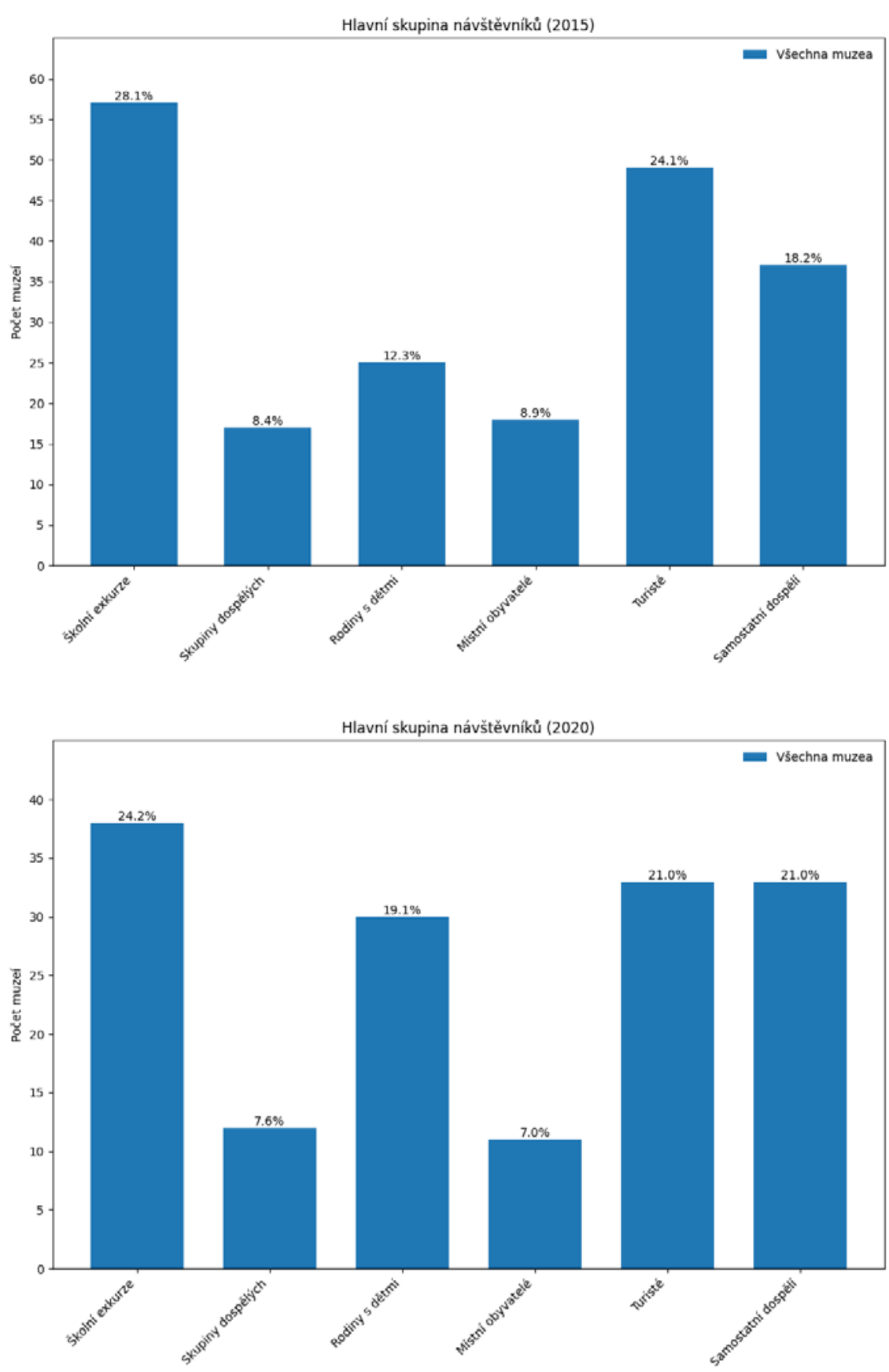

Graf č. 3: Nejdůležitější cílové skupiny - V2015

Graf č. 4: Nejdůležitější cílové skupiny - V2020

29 SMIRAGLIA, Christina a Lynn BAUM, 2018. Evalution and Audience Research in Museums: Past, Present, Future. In: The State of Museums: Voices from the Field. 1. vyd. United Kingdom: MuseumsEtc, s. 88-119. ISBN 978-1-912528-09-7, s. 97-98. skupinu školní exkurze (28\%), na druhém místě byli turisté $(24,1 \%)$, třetí dospělí samostatní návštěvníci $(18,3 \%)$ a čtvrtou skupinou rodiny s dětmi $12,3 \%$. Ve vzorku V2020 zůstává pořadí stejné, školní exkurze (23,9\%), turisté (21,3\%), dospělí samostatní návštěvníci $(20,6 \%)$ a rodiny s dětmi (19,4\%). Rozložení cílových skupin je však rovnoměrnější - snižuje se dominance školních exkurzí a posiluje se význam rodin s dětmi.

Pro první oblast, která je zaměřená na šíri využívání nových médií jako muzejních exponátů, bylo nutné zjistit, kolik muzeí se v posledních 10 letech modernizovalo. $\mathrm{V}$ roce 2015 deklarovalo 85,7 \% muzeí, že v posledních 10 letech provedlo změnu v expozicích, v roce 2020 to bylo 89,7\% muzeí. Ukazuje se, že modernizace expozic je v českých muzeích intenzivní (graf č. 5 a 6).

V dotazníku z roku 2020 měli respondenti uvést, jakou celkovou koncepci má jejich nejmodernější expozice, přičemž vybírali ze 6 typů a jako sedmou možnost mohli uvést, že rámec nedovedou posoudit. Otázka směřovala $\mathrm{k}$ tomu, zda muzejníci pohlížejí na výstavy jako na celek a jestli využívají integrální design pomocí celkové koncepce expozice (graf č. 7). Nejčastější koncepcí byla tematická prezentace bez chronologického řazení (33,1% muzeí). Druhou nejčastější odpovědí bylo právě „Nedovedu posoudit", kterou vybralo $23,6 \%$ respondentů. Oproti tematickému řazení bylo výrazně méně v 16,6 \% případů využito chronologické koncepce. Ostatní typy nedosahovaly ani $10 \%$.

\section{Nová média jako exponáty a využívání digitalizované sbírky}

Pestrost muzejní prezentace podporuje různé potřeby návštěvníků, vychází vstříc odlišným vzdělávacím stylům a zamezuje únavě. $\mathrm{V}$ této práci jsou muzea, která mají alespoň 4 moderní formy obsahu, považována za novomediální, přičemž respondenti v roce 2015 vybírali z 11 novomediálních typů, v roce 2020 z 10 (graf č. 8 a 9). Čtyři různé druhy novomediálních exponátů byly zvoleny proto, že se jedná o takovou míru implementace moderních prvků, která zvyšuje rozmanitost expozic a tvoří dostatečně velkou protiváhu ke klasickým výstavním elementům. Z modernizovaných muzeí v roce 2015 $(85,7 \%)$ je novomediálních institucí s minimálně 4 moderními prezentačními prvky pouze $27 \%$, přičemž je patrný rozdíl mezi malými muzei, kde se nová média využívají výrazně méně. $Z$ modernizovaných muzeí v roce 2020 je novomediálních institucí již 71,6\%. Během pěti let se jedná o nárůst o 44,6 procentních bodů. Nejčastějšími novomediálními exponáty jsou audiovizuální exponáty a vzrostl počet muzeí, která nabízí hands-on aktivity (graf č. 10 a 11). 


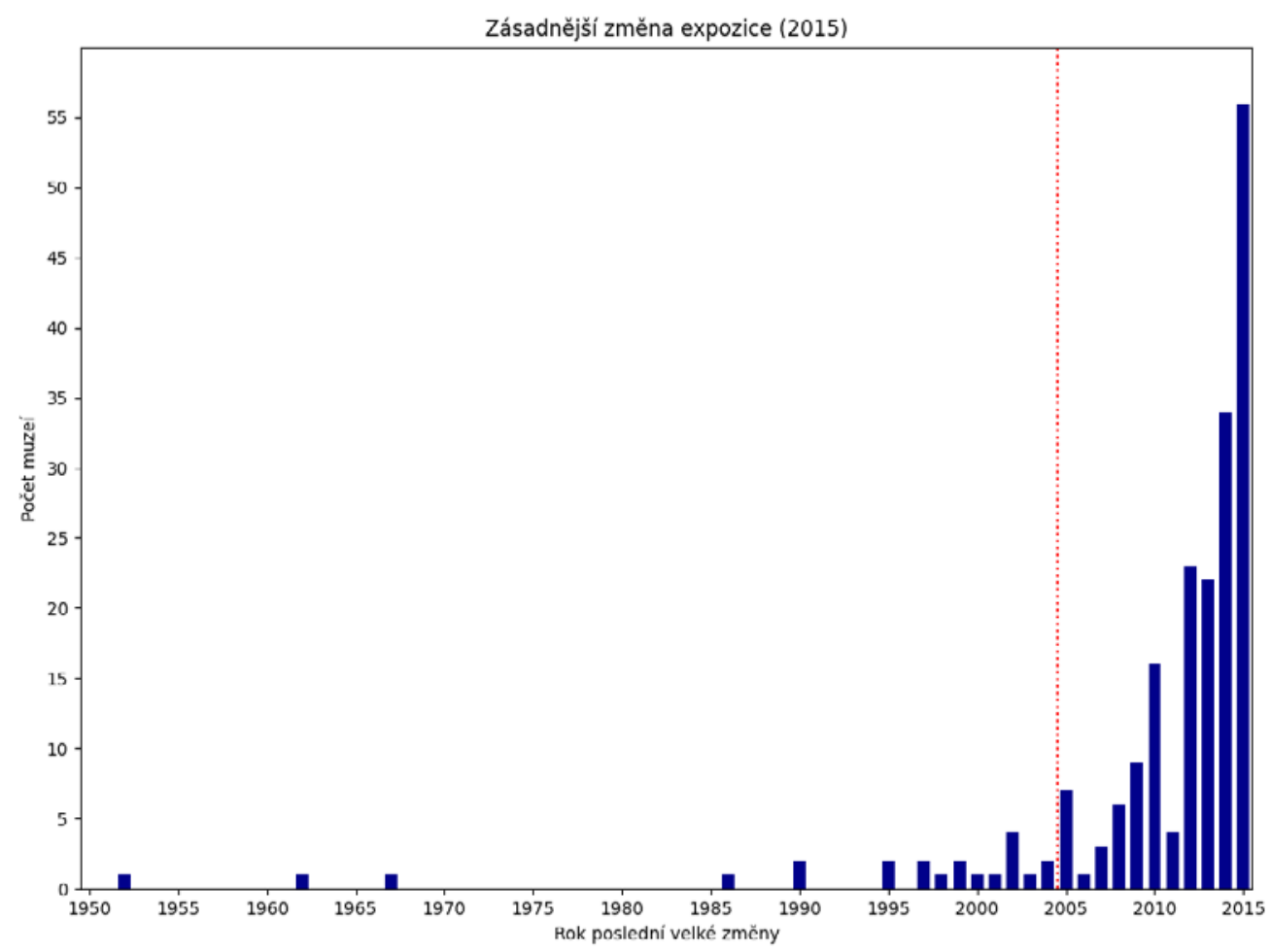

Graf č. 5: Rok poslední zásadnější změny v muzeu - V2015

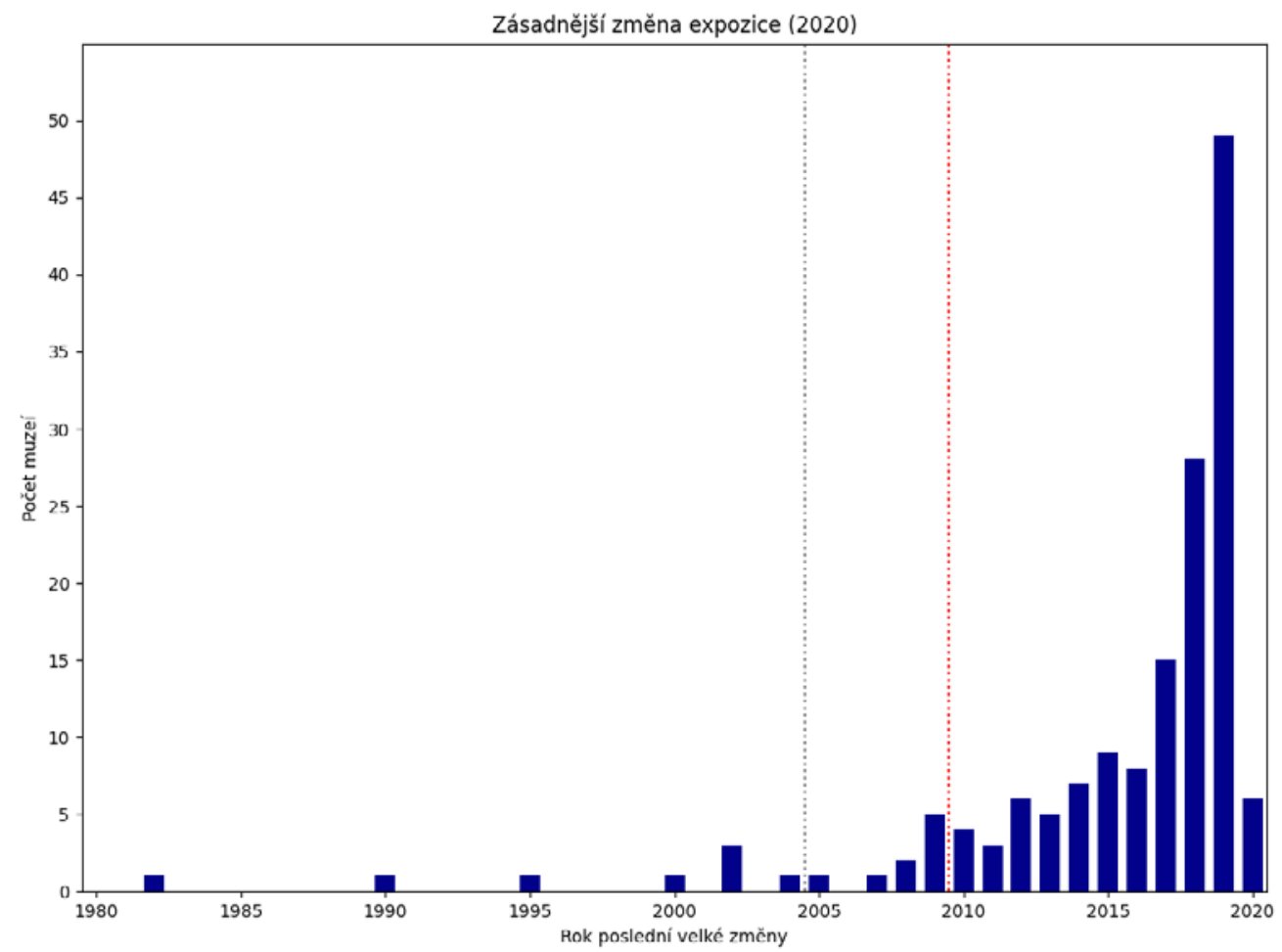

Graf č. 6: Rok poslední zásadnější změny v muzeu - V2020
30 DOMAGK, Steffi, Ruth N. SCHWARTZ a Jan L. PLASS, 2010. Interactivity in multimedia learning: An integrated model. Computers in Human Behavior [online]. 26(5), 1024-1033. ISSN 07475632. Dostupné z: doi:10.1016/j. chb.2010.03.003

31 Tamtéž.

32 HORN, Michael S., Amartya BANERJEE, David BAR-EL a Izaiah Hakim WALLACE, 2020. Engaging families around museum exhibits: comparing tangible and multi-touch interfaces. In: IDC '20: Proceedings of the Interaction Design and Children Conference [online]. New York: Association for Computing Machinery, s. 556-566. ISBN 978-14503-7981-6. Dostupné z: doi:10.1145/3392063.3394443 33 EVANS, Chris a Nicola J. GIBBONS, 2007. The interactivity effect in multimedia learning. Computers \& Education [online]. 49(4), 1147-1160. ISSN 03601315. Dostupné z: doi:10.1016/j. compedu.2006.01.008 34 JENKINS, Henry, 2008. Convergence Culture: Where Old and New Media Collide. 1. vyd. USA: NYU Press. ISBN 978-0814742952, S. 112.

35 MANOVICH, Lev, 2018. Jazyk nových médií. 1. vyd. Praha: Univerzita Karlova. ISBN 978-80-246-2961-2, s. 87. 36 ŠOBÁÑOVÁ, Petra a Jolana LAŽOVÁ, 2016. Muzeum versus digitální éra. 1. vyd. Olomouc: Univerzita Palackého v Olomouci. ISBN 978-80-2445023-0. s. 36.

37 EVERBROECK, Christine Van, Sandra VERHULST a Sandrine PLACE, 2011. Let's Play Soldiers: Learning While Playing. In: Museums at Play: Games, Interaction and Learning. 1. vyd. United Kingdom: MuseumsEtc,

s. 112-127. ISBN 978-1-90769713-5, s. $114-117$.

38 ŠOBÁŇOVÁ, Petra a Jolana LAŽOVÁ, 2016. Muzeum versus digitální éra. 1. vyd. Olomouc: Univerzita Palackého $v$ Olomouci. ISBN 978-80-2445023-0, s. 95-99. 
39 KRYNEK, Ondřej, 2019. Národní muzeum otevřelo ve spojovací chodbě digitální expozici Momenty dějin.

DesignMag.cz [online]. 2020.

ISSN 2464-6202. Dostupné

z: http://www.designmag.czl

umeni/85769-narodni-mu-

zeum-otevrelo-ve-spojovaci-chodbe-digitalni-expozici-momenty-dejin.html

40 DOWNE, Louise, 2011. Mobile Gaming - No Strings Attached? In: Museums at

Play: Games, Interaction and Learning. 1. vyd. United Kingdom: MuseumsEtc, s. 576583. ISBN 978-1-907697-13-5.

41 ATES, Aysun a Jennie F. LANE, 2019-12-03. Analysing School-Museum Relations to Improve Partnerships for Learning: A Case Study. Education and Science [online]. 45(201), 231-246. ISSN 1300-1337. Dostupné z: doi:10.15390/EB.2019.8017 42 BEALE, Katy, 2011. Museums at Play: Games, Interaction and Learning. 1. vyd. United Kingdom: MuseumsETC. ISBN 978-1-907697-13-5.

43 SOARES, Bruno Brulon, ed., 2019. A History of Museology: Key authors of museological theory. Paris: International commitee for Museology - ICOFOM. ISBN 978-92-9012-456-6.

44 BAWDEN, David a Lyn ROBINSON, 2017. Úvod do informační vědy. Doubravník: Flow. ISBN 978-80-88123-10-1.

45 MANOVICH, Lev, 2018. Jazyk nových médií. 1. vyd. Praha: Univerzita Karlova. ISBN 978-80-246-2961-2. 46 Adresár muzeí a galerii České republiky, 2015. Asociace muzeí a galerií $C R$ [online]. Praha: Asociace muzeí a galerií ČR [cit. 2018-03-29].

Dostupné z: http://www.cz-museums.czladresarl

47 NIPOS, 2019. Kultura České republiky 2019 v čislech: Vybrané údaje ze statistických šetření [online]. 2019. 1. vyd.

Praha: Národní informační a poradenské středisko pro kulturu. Dostupné z: https://www. statistikakultury.cz/wp-content/ uploads/2020/08/Kultura_v_cislech_2019-web.pdf

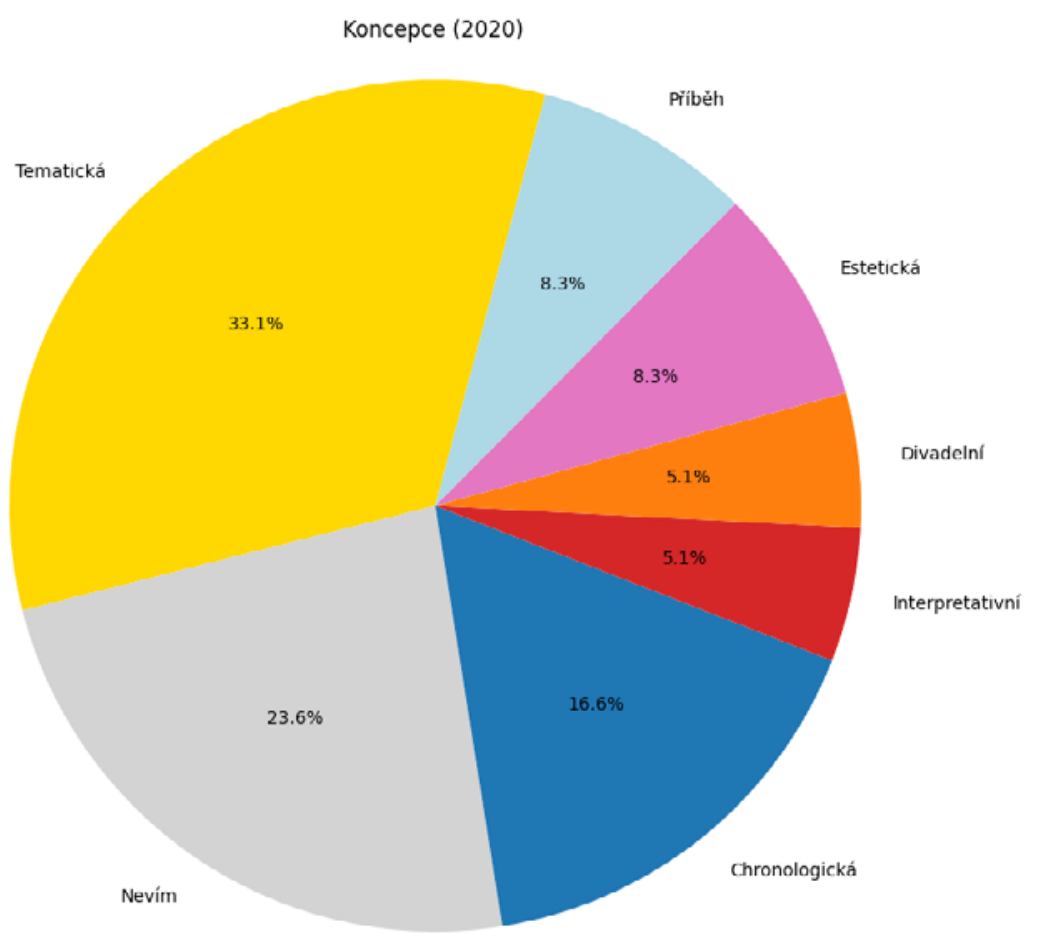

Graf č. 7: Koncepce výstavy, která využívá nejvíce technologických prvků - V2020

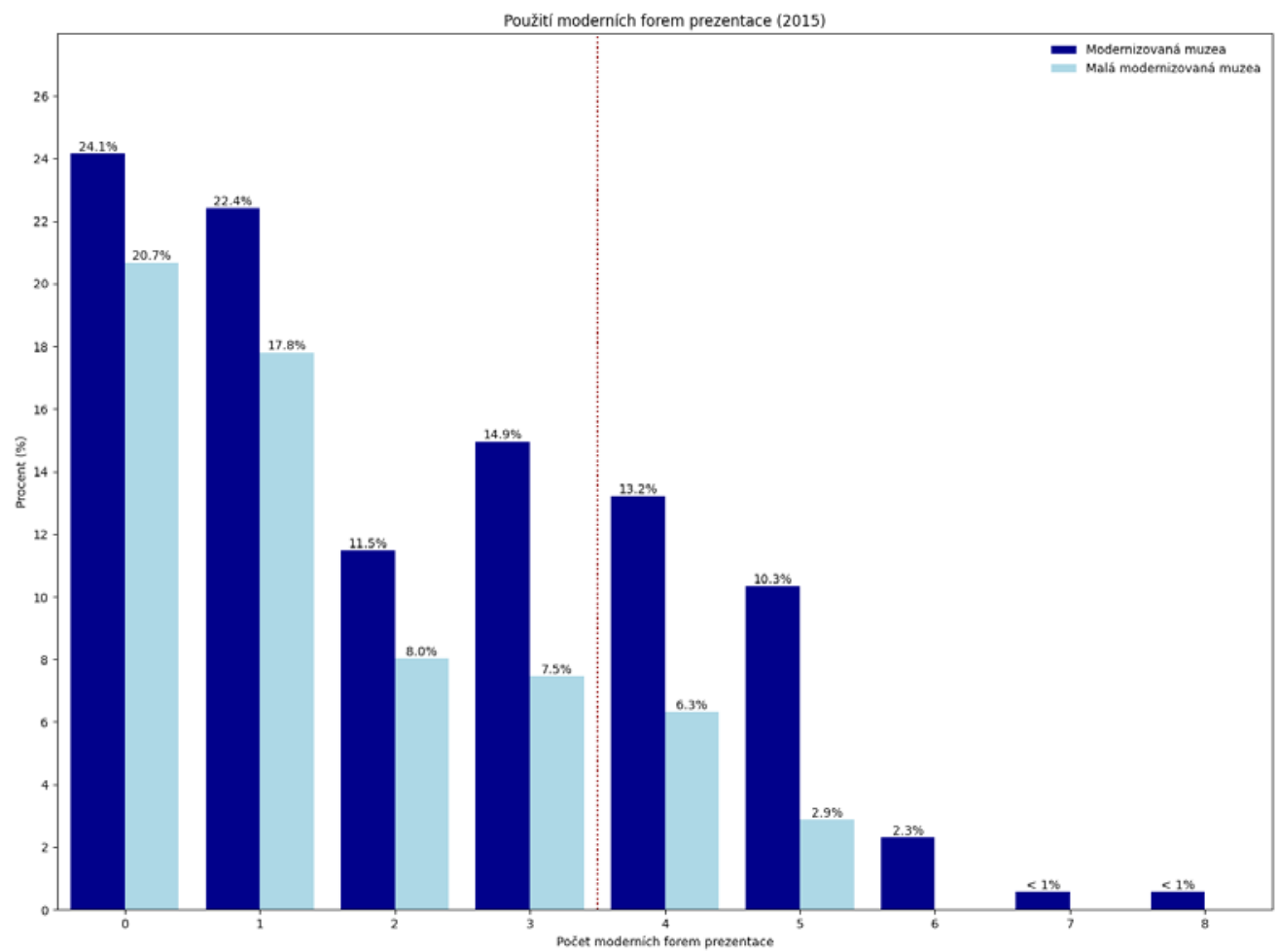

Graf č. 8: Počet novomediálních forem, které využívají muzea modernizovaná v letech 2005-2015 - V2015 


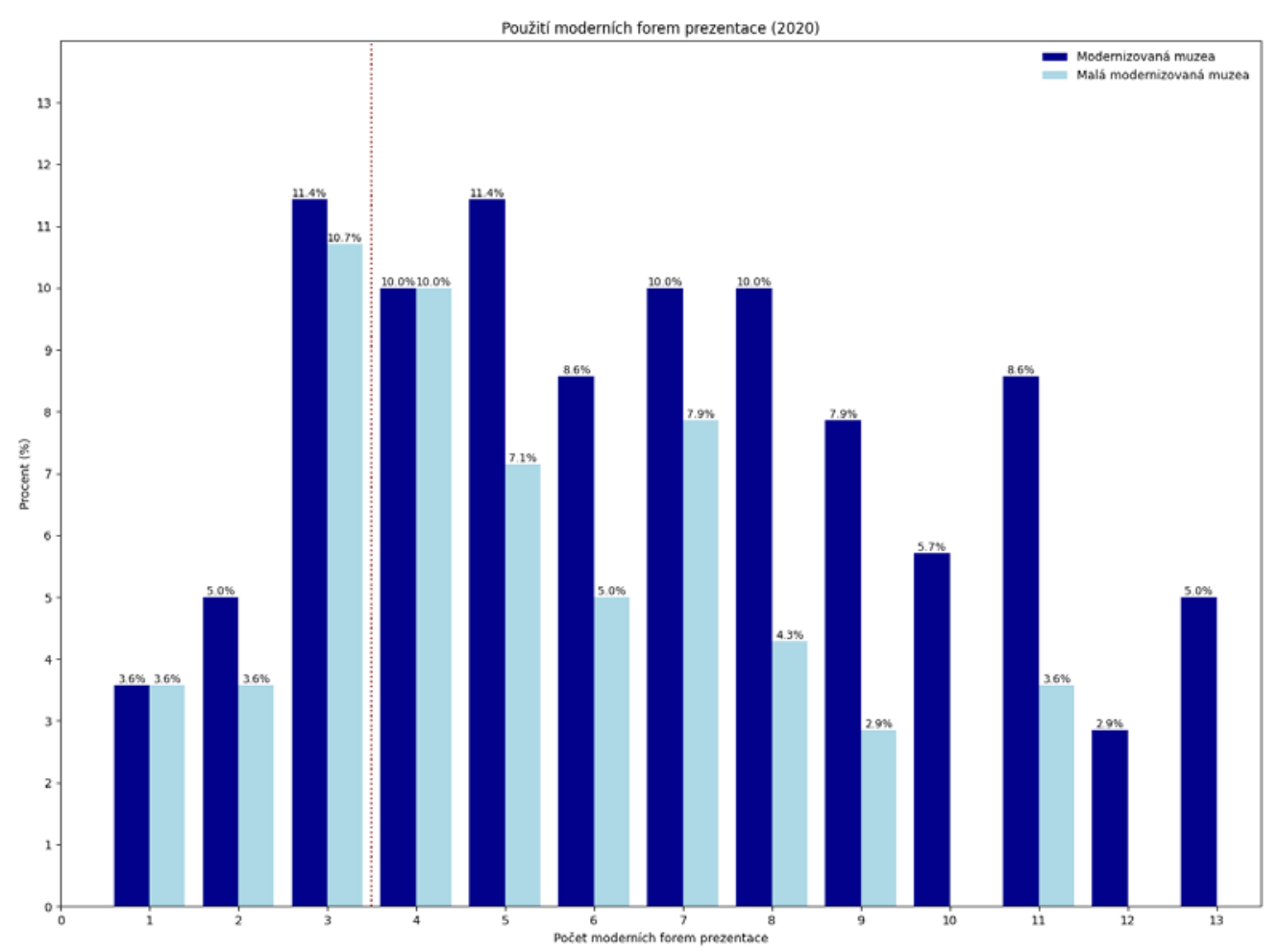

Graf č. 9: Počet novomediálních forem, které využívají muzea modernizovaná v letech 2010-2020 - V2020

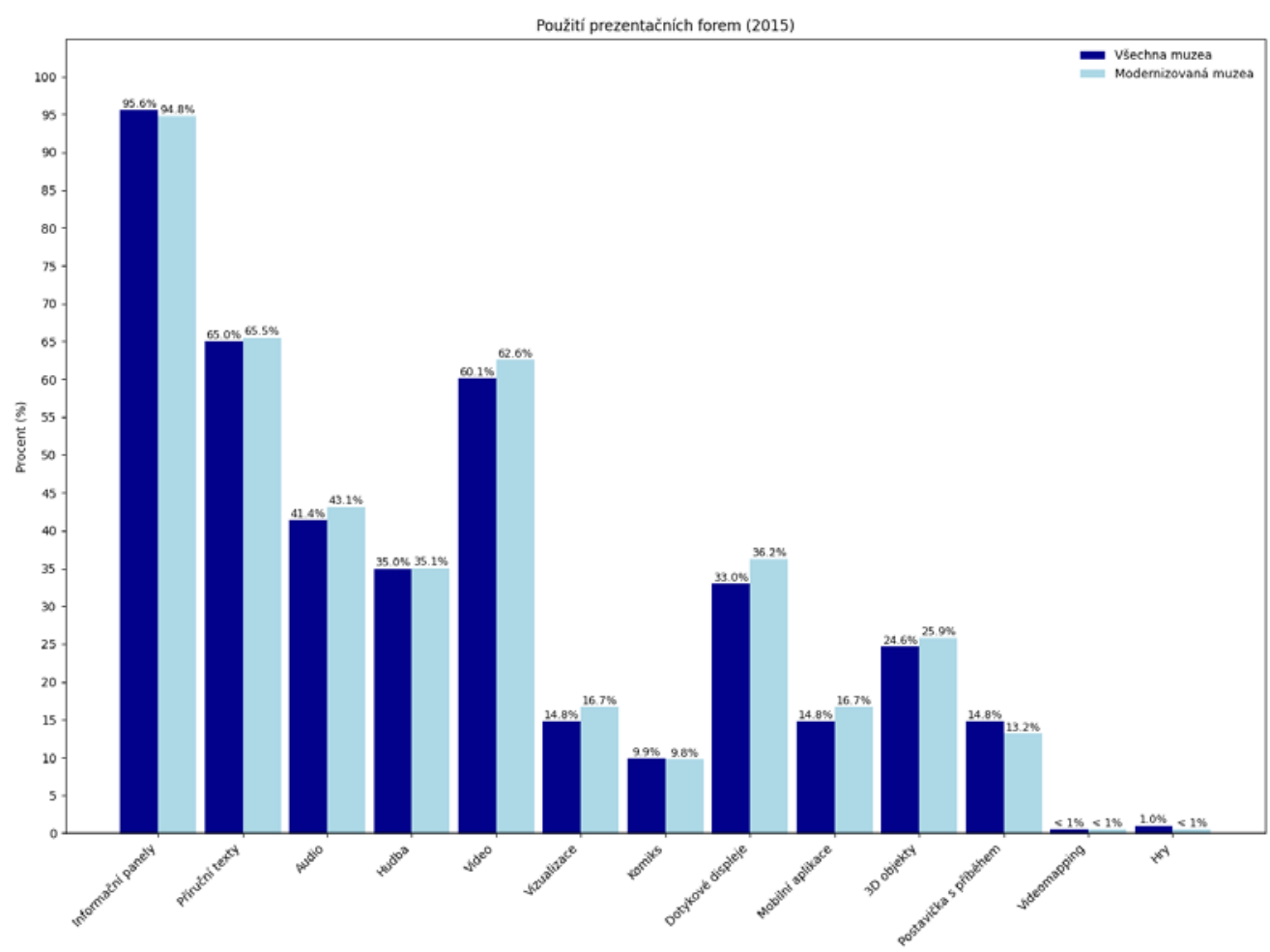

Graf č. 10: Typy exponátů využívaných v expozicích - V2015

48 MCKENNA-CRESS,

Polly a Kamien Janet A., 2013. Creating Exhibitions: Collaboration in the Planning, Development, and Design of Innovative Experiences. 1. vyd. USA: Wiley. ISBN 978-1-11830634-5, s. 22-23.

49 CANTILLON, Zelmarie a Sarah BAKER, 2018-11-28. DIY Heritage Institutions as Third Places: Caring, Community and Wellbeing Among Volunteers at the Australian Jazz Museum. Leisure Sciences [online]. 2018, 1-19. ISSN 0149-0400. Dostupné z: doi:10.1080/01490 400.2018.1518173

50 FALK, John H. (2019, April). Emotions and museum-going. Presentation at the 3rd International Conference on Audience Research and Development, Connected Audience 2019 Berlin, Berlin, Germany. 


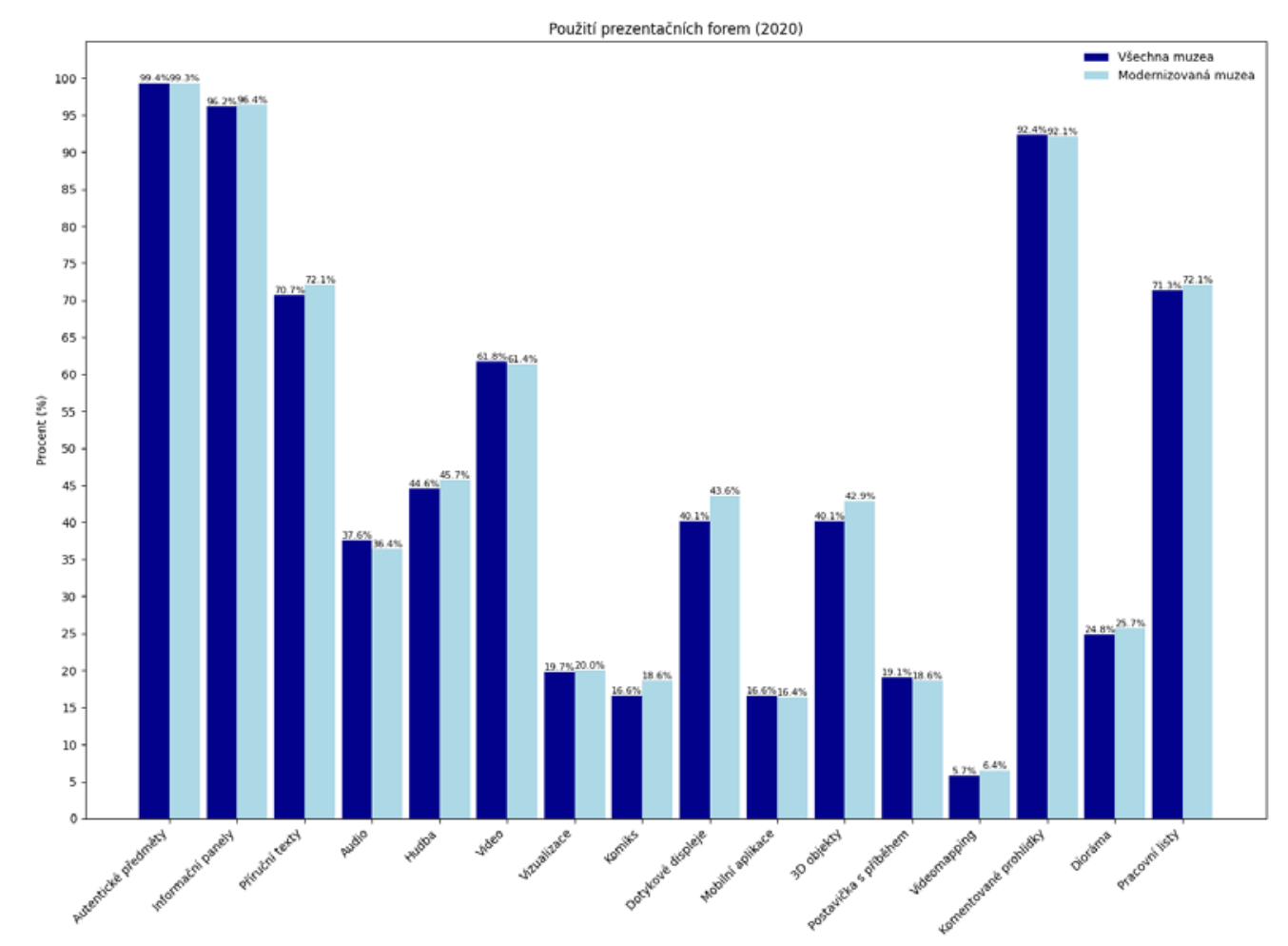

Graf č. 11: Typy exponátů využívaných v expozicích - V2020

Digitalizovaná sbírka neslouží jen potřebám muzejníků, ale je využívána k online výstavním projektům. Zjištovala jsem, zda muzea nabízejí 3D virtuální prohlídky prostor, zpř́ístupňují databázi, vytvářejí kurátorsky a didakticky ucelenou virtuální výstavu a v roce 2020 i to, zda jsou zapojeny do online projektů typu eSbirky či Europeana (graf č. 12 a 13). V roce 2015 nezpř́stupňovalo sbírku žádným z uvedených způsobů 45,3\%. 3D virtuální prohlídku nabízelo návštěvníkům $30 \%$ muzeí, databázi rovněž $30 \%$ a virtuální výstavy pouze $8,9 \%$ muzeí. Celkové využívání online výstavních projektů $\mathrm{v}$ roce 2020 kleslo, protože žádným způsobem nezpř́stupňuje digitální sbírku online $56,1 \%$. Největší ústup je patrný u 3D virtuální prohlídky (pokles na 13,5\%). Online databázi zpř́stupňuje $24,5 \%$ muzeí, 18 \% muzeí je zapojeno do online projektů a nejméně využívaným způsobem je stále virtuální výstava, kterou uspořádalo 10,3\% muzeí.

\section{Doprovodné programy, hra v muzeu}

\section{a aktivní návštěvník}

Doprovodné programy umožňují hlubší práci s návštěvníkem a jeho aktivizaci. V roce 2015 nabízí doprovodné aktivity $94,6 \%$ institucí. Dvě různé aktivity najdeme u $75 \%$ muzeí, polovina institucí má 4 různé druhy a čtvrtina dokonce 5 . Nejčastější jsou přednášky a besedy, které zařazuje do programu 75,8 \% muzeí, následují workshopy u $67 \%$ muzeí (graf č. 14 a 15).

V roce 2020 se dotazník zaměřil na herní prvky v expozicích, protože by opakování otázek zaměřených na doprovodné programy nepřineslo nová zjištění. Hry nabízí 82,2\% muzeí. Nejrozšířenější herní aktivitou jsou kvízy, které využívá $67 \%$ muzeí, $64,8 \%$ institucí poskytuje omalovánky nebo vystřihovánky. Hry na muzejních počítačích či tabletech nabízí $15,9 \%$ a hry v aplikaci pak pouze 2,9\% muzeí. Většina herních prvků v českých muzeích je ne-technologická (graf č. 15). 
Dále jsem zjištovala, co návštěvníci v muzeích dělají a jak jsou aktivní. Chování návštěvníků $\mathrm{v}$ expozicích souvisí s řadou faktorů. Důležitý je design výstav, atmosféra při konkrétní návštěvě, očekávání nebo to, zda návštěvník prochází expozicí sám, nebo s dalšími lidmi. Respondenti posuzovali míru toho, co návštěvníci běžně $v$ muzeích dělají, u nejdůležitějších aktivit, se kterými se návštěvníci mohou běžně setkat (např. prohlížení sbírkových předmětů, čtení textů, hraní her, používání technologií, komunikace), a to na škále vůbec-trochu-stř̌edně-výrazně-dominantní činnost. Ukázalo se, že základní schéma se během 5 let téměř nemění a zůstává až na drobné změny stejné, proto přikládám pouze graf z roku 2020 (graf č. 17).

Zhodnocena byla i relativní váha prováděných činností (graf č. 18 a 19), kdy každé možnosti z uvedené škály byla přiřazena číselná hodnota, která ve výsledku dala kladné či záporné celkové hodnoty. Slovní vyjádření "Vůbec" bylo nahrazeno číselnou hodnotou -2, "Trochu“ hodnotou -1, „Středně“ 0,5, „Výrazně“ +1 a „Dominantní činnost" se stalo ekvivalentem pro hodnotu +2. Ve V2015 jsou výrazně zastoupené činnosti, které spadají do činností pasivních. Čtení textů, které jsou výraznou součástí expozic ve formě informačních panelů a príručních textů, však nedosahuje tak kladných hodnot. Jediná činnost ze skupiny aktivních, která dosahuje v celku mírně pozitivní hodnoty, je komunikace mezi návštěvníky. To ukazuje na důležitost sociálního rozměru při návštěvě muzea. Na hranici kladných hodnot se nachází pokládání otázek průvodci. Používání technologií nebylo v roce 2015 př́liš zastoupeno, nebot většina muzeí je takřka nepoužívala. $O$ pět let později se situace př́liš̌ nemění a základní schéma aktivity návštěvníků zůstává stejné. Pasivní činnosti stále převládají, nicméně mírně posílilo kladení otázek průvodcům, což ukazuje na větší dialogičnost komentovaných prohlídek.

\section{Výsledky z roku 2015 a 2020 přinesly} následující poznatky:

1. Česká muzea se inovují a ve většině muzeí dochází ke změnám expozic.
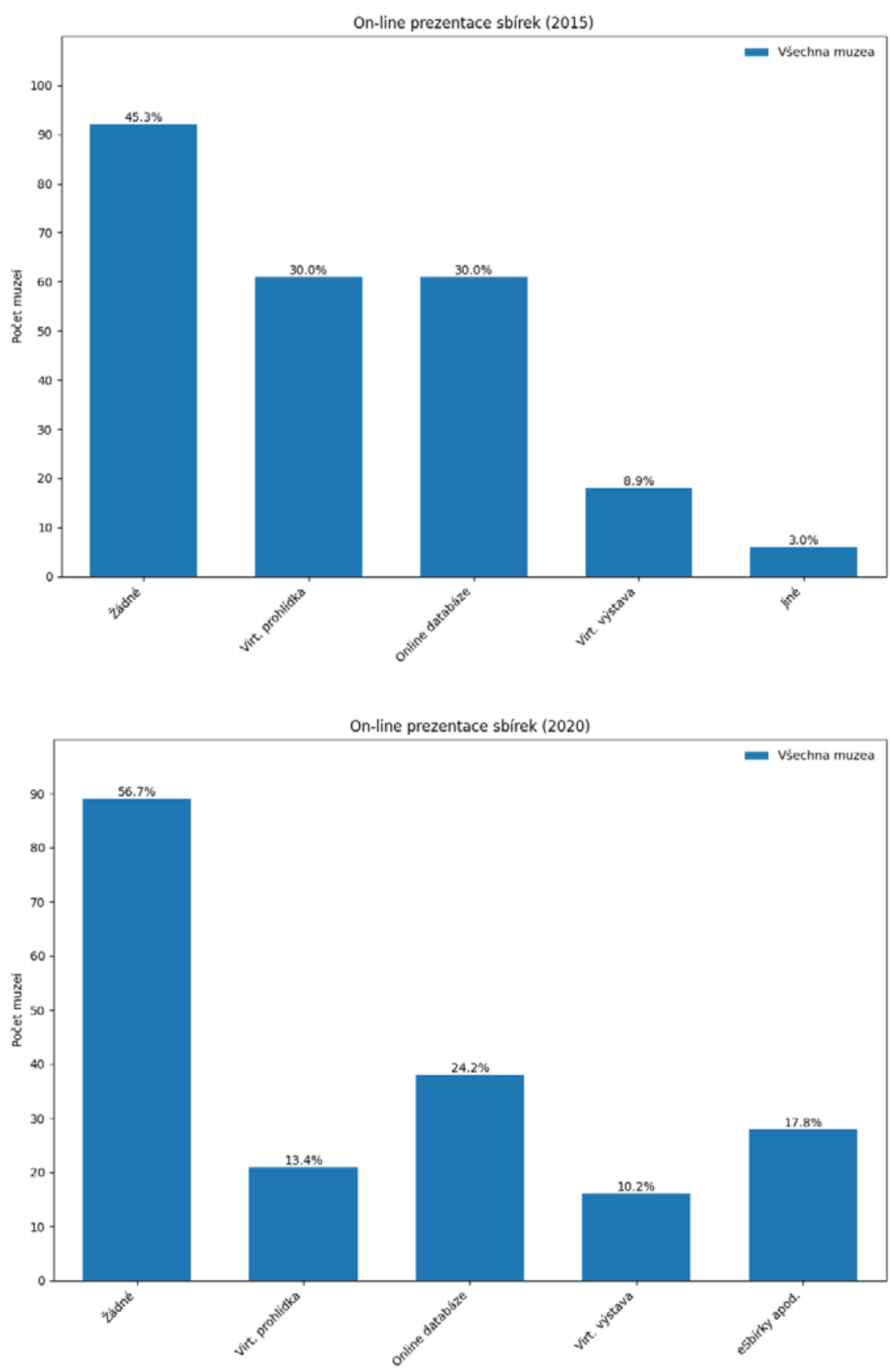

2. V roce 2020 je nejčastější koncepcí tematické řazení expozice a $23,6 \%$ respondentů koncepci neurčilo.

3. Během 5 sledovaných let výrazně vzrostlo využívání nových médií jako exponátů. Kritérium minimálně 4 novomediálních forem obsahu splňovalo $27 \%$ muzeí v roce 2015 a v roce 2020 již $71,6 \%$. V míře užívání nových médií jako exponátů najdeme rozdíly mezi malými muzei, kde se používají méně, a muzei středními a velkými, kde se využivají více.

4. Mezi nejčastější novomediální exponáty, které najdeme ve více než třetině muzeí $\mathrm{v}$ roce 2020, patří video, hudba, dotykové displeje, 3D objekty a audio.
Graf č. 12: Prezentace digitalizované sbírky - V2015

Graf č. 13: Prezentace digitalizované sbírky - V2020 


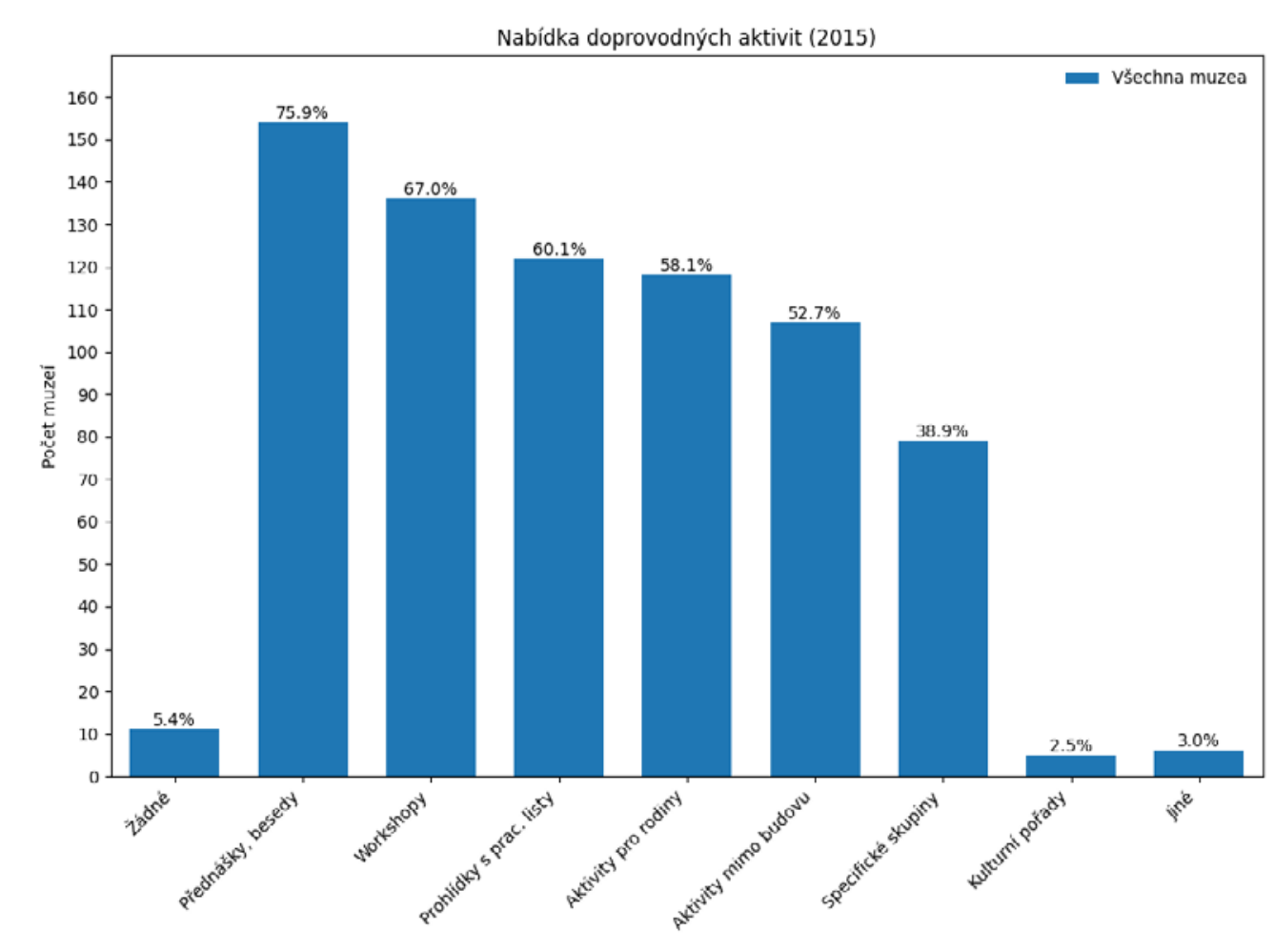

Graf č. 14: Jaké doprovodné programy muzea nabízejí - V2015

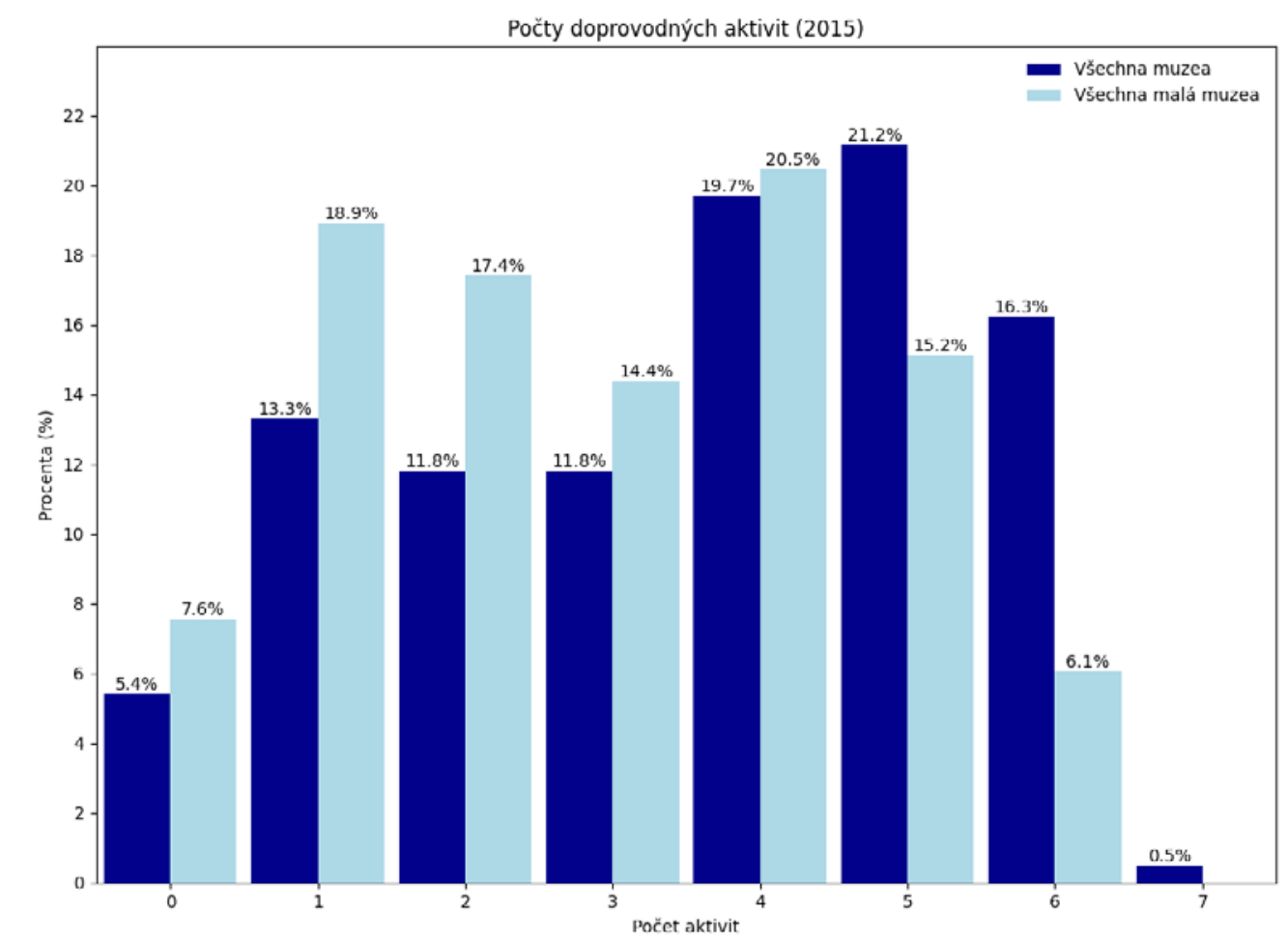

Graf č. 15: Počet aktivit, které muzea nabízejí - V2015 


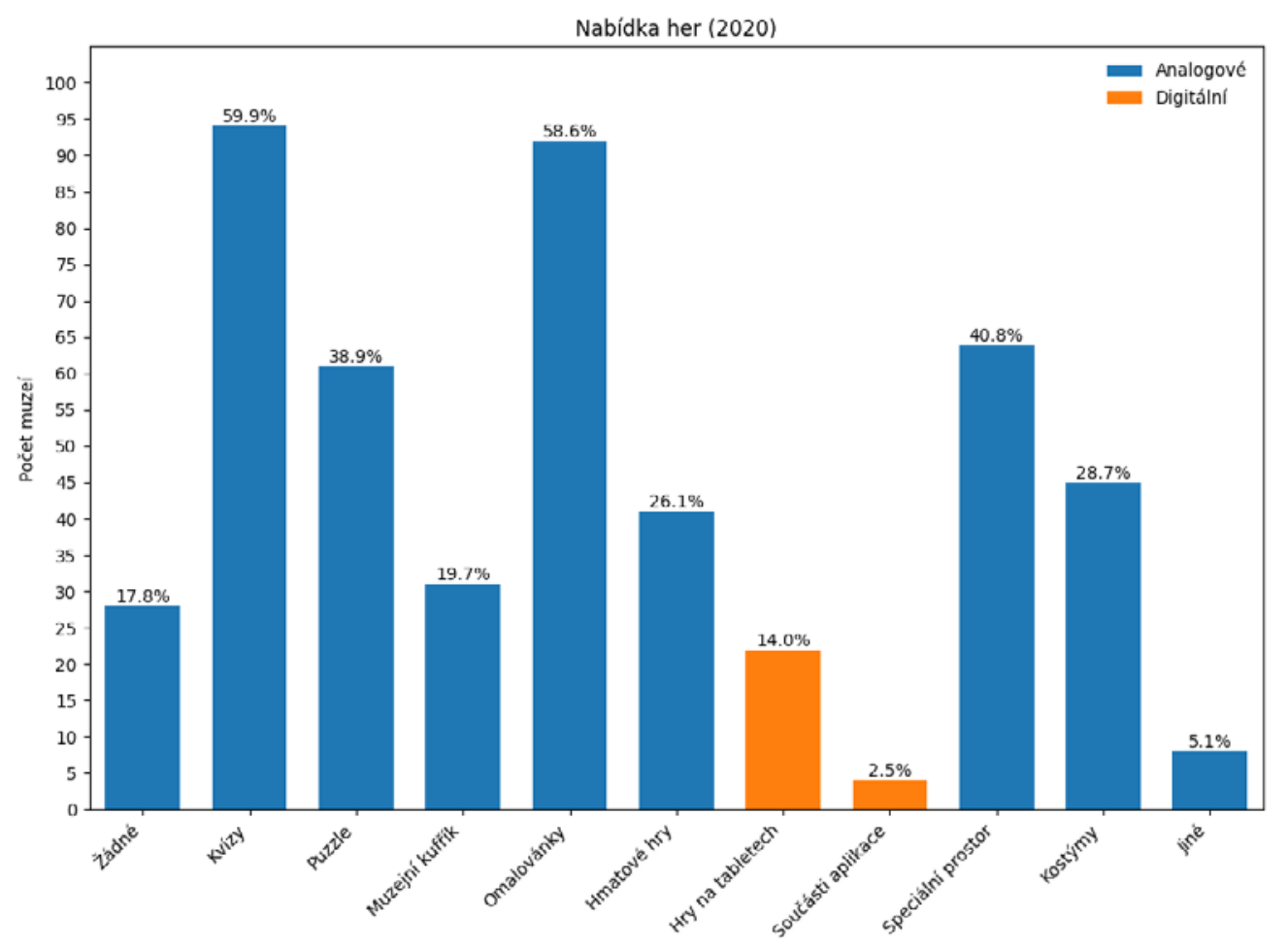

Graf č. 16: Herní aktivity v expozicích - V2020

5. Mezi rokem 2015 a 2020 se snížilo využívání digitalizované sbírky k výstavním online projektům. Nejvíce klesla nabídka 3D virtuálních prohlídek.

6. Návštěvníci se mohou účastnit řady doprovodných akcí a většina muzeí nabízí herní aktivity. Podle muzejníků jsou však návštěvníci stále spíše pasivní.

\section{Diskuse}

Výsledky ukazují, že česká muzea se modernizují a dochází ke změnám v expozicích. Nejvýznamnějším zjištěním prvního šetření byl rozdíl v používání novomediálních exponátů $\mathrm{v}$ malých institucích, kde pracuje do 10 zaměstnanců, a ve středních a velkých, kde se využívají výrazně více. Zároveň je však malých institucí nejvíce (65\% v roce 2015, 59,2\% v roce 2020). V roce 2015 se ukázalo, že nová média v expozicích nejsou výrazněji využívána - novomediálních muzeí bylo $27 \%$. $\mathrm{V}$ roce 2020 je to již 71,6\% muzeí. Nárůst ve využívání nových médií jako exponátů o 44,6 procentních bodi̊ je velmi výrazný. Celkově se u tohoto hlediska jedná o největší rozdíl mezi lety 2015 a 2020 ze všech zkoumaných oblastí. Pokud se podíváme na typy využívaných novomediálních exponátů během posledních 20 let, data ukazují, že zavádění novomediálních forem do muzeí postupuje od forem produkčně jednodušších $\mathrm{k}$ těm náročnějším a muzea tedy postupně nabývají jistotu (graf č. 20). Využívání digitalizované sbírky $\mathrm{k}$ online projektům zatím není v českých muzeích příliš rozšírené a 3D virtuální prohlídky se zdají být zastaralé.

Prezentace komplexních témat je trendem v muzejní prezentaci. Výsledky ukázaly, že nejčastější koncepce v českých muzeích je v roce 2020 tematické řazení, méně pak chronologické pořadí a 23,9\% respondentů koncepci neidentifikovali. Výsledky by mohly naznačovat, že česká muzea sice začala novomediální exponáty více využívat, ale spíše jako další formy exponátů, a využívání nových médií se neodrazilo 


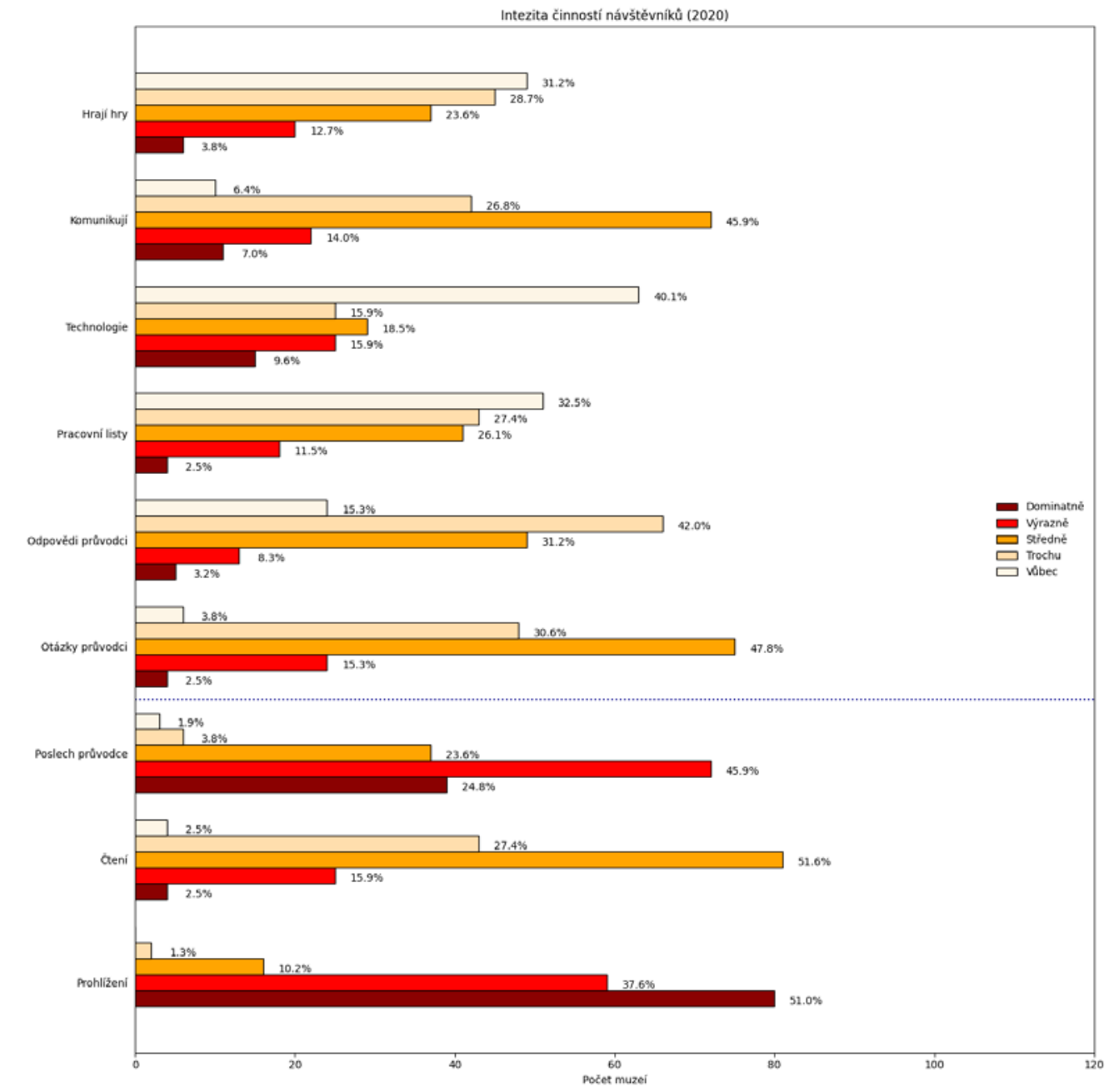

Graf č. 17: Co návštěvníci v muzeu dělají - V2020

ve změně celkového pojetí expozic a nejsou integrální součástí výstavnického designu. Zdá se, že způsob přemýšlení o expozicích jako o komplexním médiu zatím není v českých muzeích více rozvinut. Návštěvníci hrají v muzeích klíčovou roli. Vstřícnost muzea $\mathrm{k}$ návštěvníkům byla posuzována na základě nabídky doprovodných programů, herních aktivit a vycházela $\mathrm{z}$ hodnocení míry toho, co návštěvníci v muzeu dělají. Česká muzea nabízejí širokou škálu doprovodných programů; alespoň jednu aktivizační metodu v roce 2015 nabízí 94,5\% muzeí, i když nejčastější jsou besedy, které často mají povahu frontálního výkladu. $\mathrm{V}$ roce 2020 82,2 \% muzeí nabízí nějakou herní aktivitu, což ukazuje, že herní prvky se stávají poměrně běžnou nabídkou muzeí. Základní schéma toho, co v muzeu návštěvníci dělají, se však příliš nemění a je možné, že muzea se sice vyvíjejí, ale návštěvníci jsou zatím konzervativní a $\mathrm{k}$ větším změnám $\mathrm{v}$ jejich chování prozatím nedochází.

Ačkoli se nemění pořadí nejvýznamnějších cílových skupin (školní exkurze, turisté, samostatní dospělí návštěvníci), je patrný posun v rozložení jejich významnosti. Na základě cílových skupin je zřejmé, že česká muzea silně vnímají svou roli ve vzdělávání a jsou spjata s turismem. Významnou roli stále hrají dospělí samostatní návštěvníci, kteří mají nejméně vyhraněné potřeby a je snadné je zaujmout i klasickou muzejní prezentací. Otázkou 


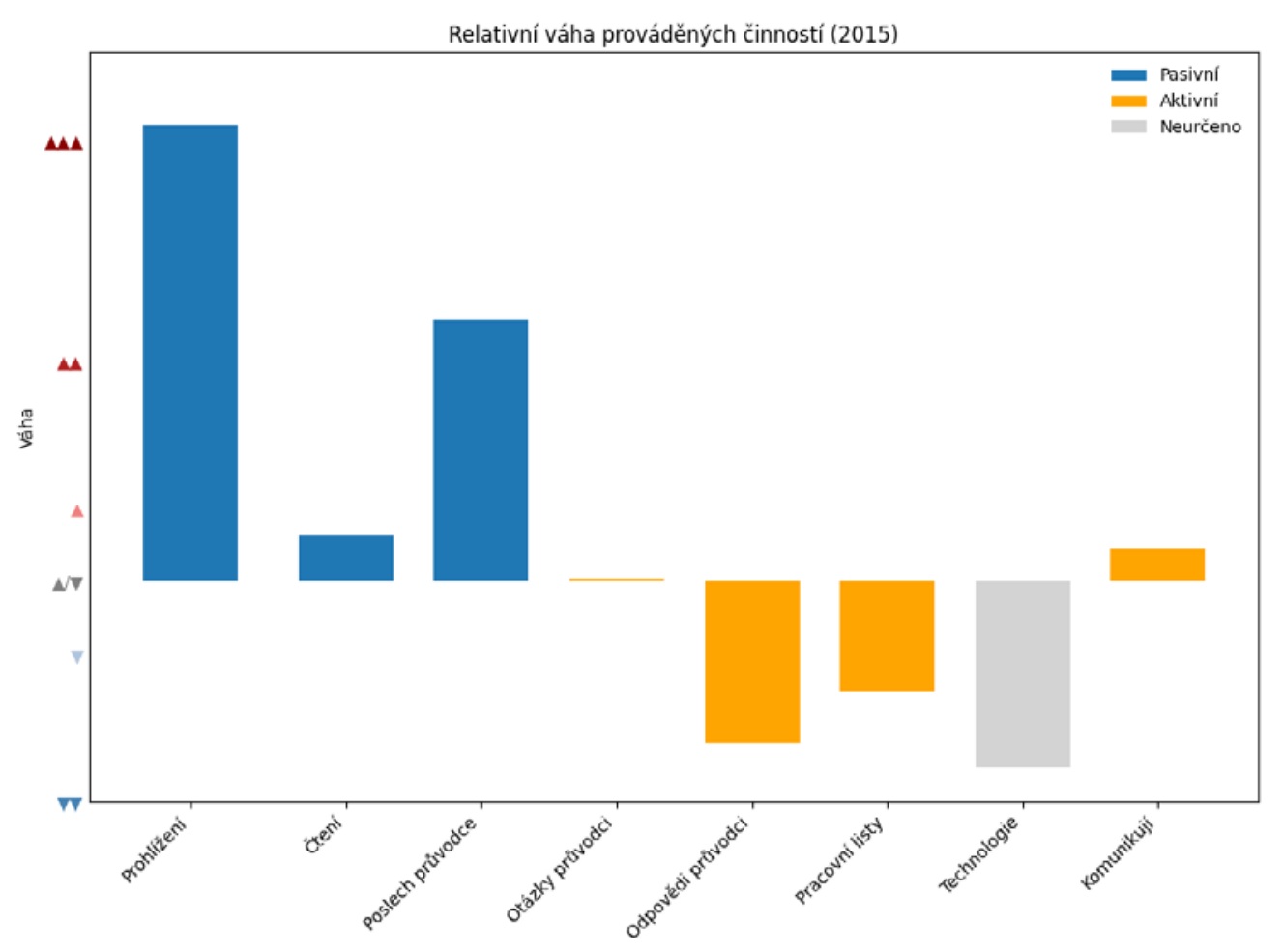

Graf č. 18: Relativní váha činností, které návštěvníci v muzeí dělají - V2015

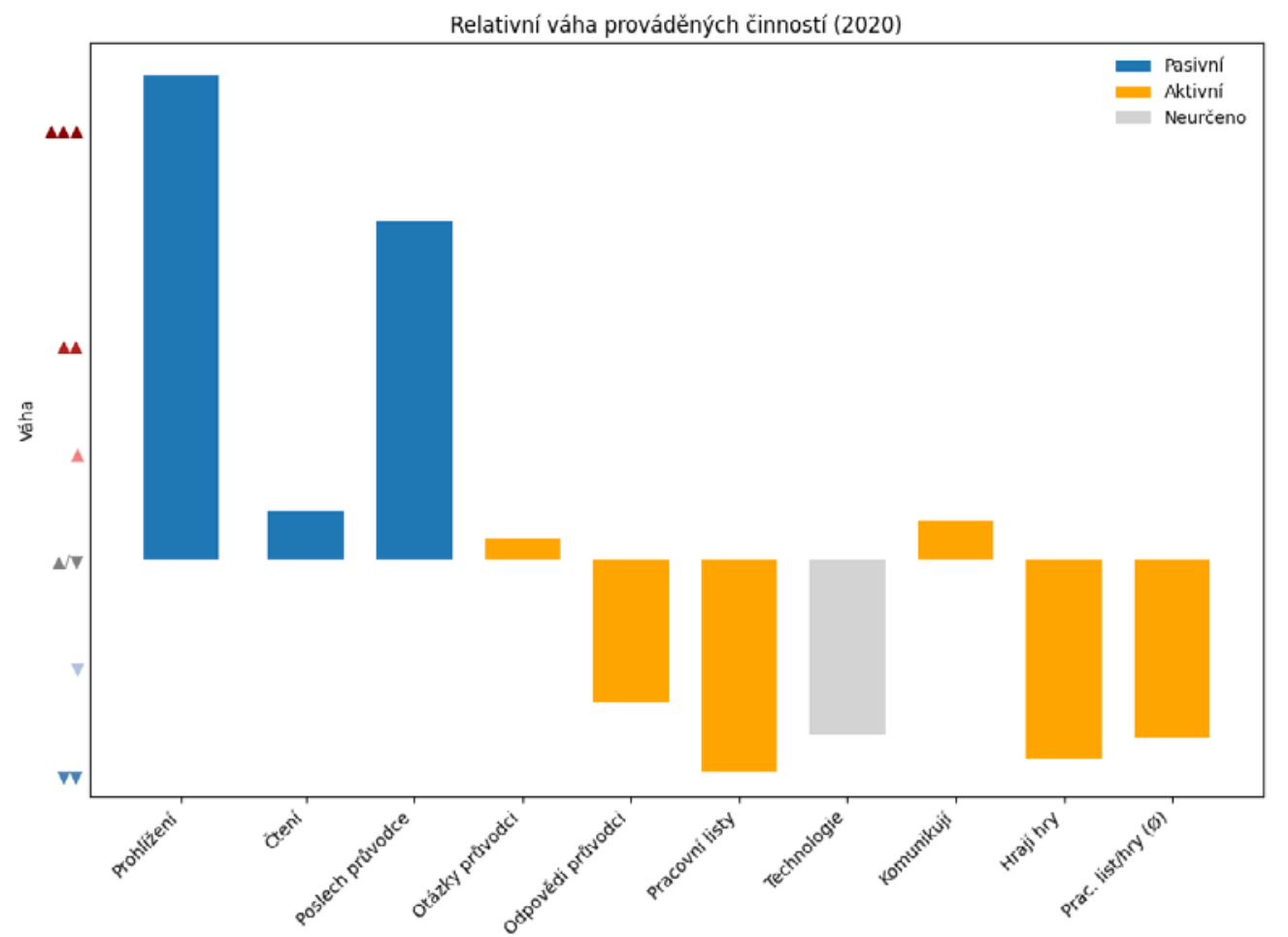

Graf č. 19: Relativní váha činností, které návštěvníci v muzeí dělají - V2020 


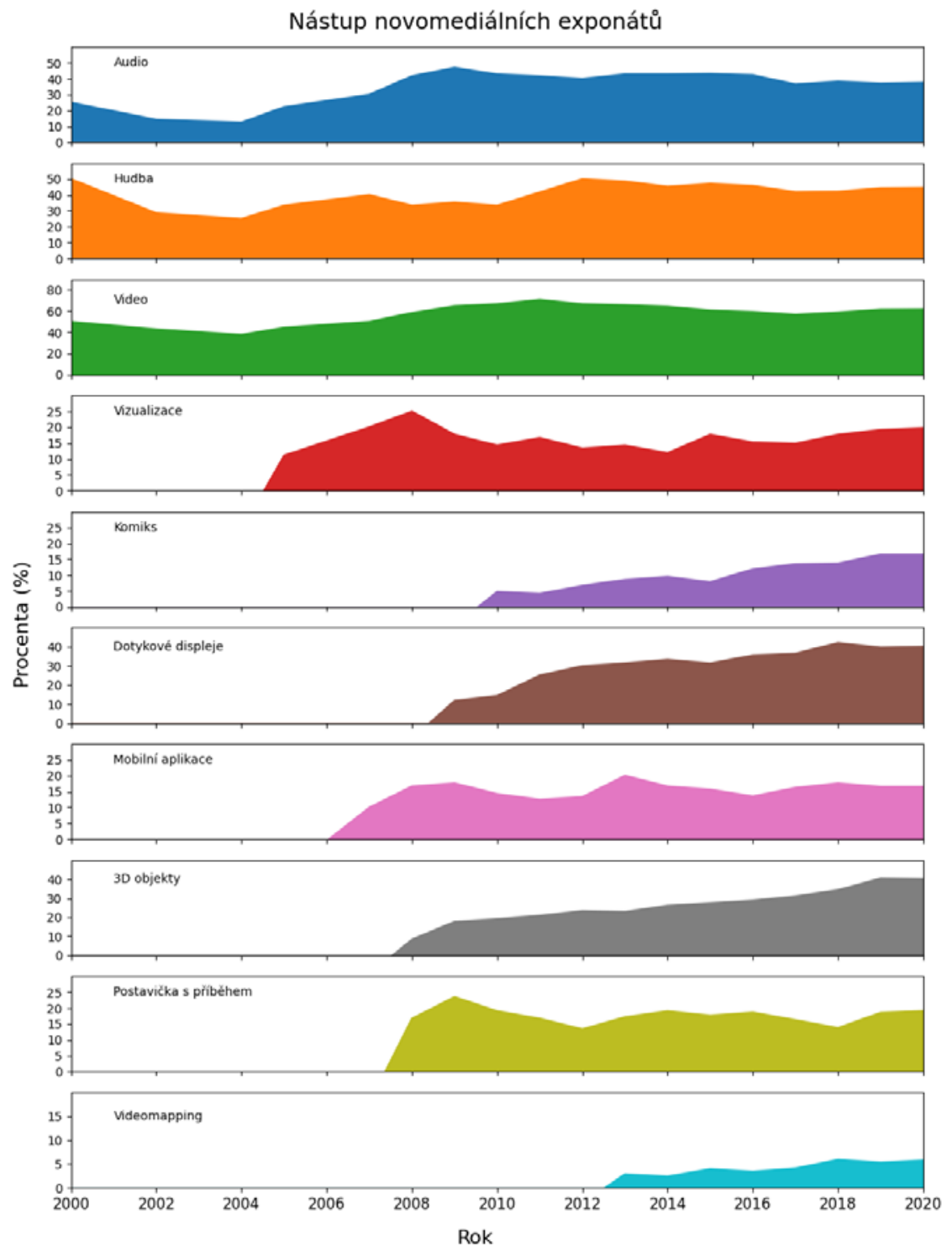

Graf č. 20: Nástup novomediálních exponátů od roku 2000 a realističtější obraz problematiky. Další silnou stránkou je velikost a různorodost vzorku a časosběrný charakter. Výzkum nezohledňuje zaměření muzeí, tedy to, zda se jedná o všeobecné, historické, umělecké či technické muzeum, což společně se standardizovanou podobou dotazníků umožňuje porovnávat instituce, které by u kvalitativního výzkumu nebyly součástí jednoho vzorku. Z povahy kvantitativního výzkumu vyplývají také jeho omezení. Dotazník je předem připraven a není možné jej na základě dosažených výsledků v průběhu výzkumu měnit, sběr dat je jednorázový. Dotazníky zodpovídali pracovníci muzeí, tudíž výsledky reflektují jejich názory, a ne např. postoje návštěvníků.

\section{Závěr}

Otázka změny a modernizace nejen českých muzeí je důležitá pro to, aby muzea v časech změny vytěžila co nejvíce ze své dobré pověsti tradičně respektovaných poskytovatelů informací a zůstala živými dějišti kultury. Studie identifikovala stav modernizace českých muzeí v klíčových oblastech, kde lze využívat nová média, a je možné ji využít jako základ pro dílčí výzkumy v úžeji definovaných oblastech. Sběr dat byl ukončen ještě před propuknutím situace s pandemií onemocnění COVID-19, a text tedy nereflektuje rok 2020, který v použivání online prezentačních postupů a technologií může výrazně změnit situaci. Opakování výzkumu bude tedy více než vhodné a je otázkou, zda se naopak muzea na základě nutnosti v současnosti pracovat $\mathrm{s}$ návštěvníky vzdáleně nezaměří více na akcentování „reálného“ zážitku. Bylo by také účelné sledovat specifickou situaci malých muzeí, kontinuálně zkoumat nastolený vývoj u prezentačních forem. Data ukázala, že celková nabídka doprovodných aktivit i her je pestrá, sami respondenti však deklarovali potřebu je vylepšit a zkvalitnit. Longitudinální výzkum ověřil, že vznikla metoda, kterou je možné sledovat trendy dlouhodobě. V dalším kole mapování trendů, které plánuji uskutečnit přibližně 
$\mathrm{v}$ roce 2025 , se chci opět věnovat tématu novomediálních exponátů, využívání digitalizované sbírky v online prostředí a herním aktivitám. Zajímavé bude sledovat vývoj v chování návštěvníků, které se $\mathrm{v}$ posledních 5 letech $\mathrm{v}$ podstatě nezměnilo.

\section{Bibliografie}

ABRAHAMSSON, Pekka, Outi SALO, Jussi RONKAINEN a Juhani WARSTA, 2002. Agile Software Development Methods: Review and Analysis. 1. vyd. Finland: VTT PUBLICATIONS 478. ISBN 951-38-6009-4.

ATEŞ, Aysun a Jennie F. LANE, 2019-12-03. Analysing School-Museum Relations to Improve Partnerships for Learning: A Case Study. Education and Science [online]. 45(201), 231-246. ISSN 1300-1337. Dostupné z: doi:10.15390/EB.2019.8017

BAWDEN, David a Lyn ROBINSON, 2017. Úvod do informační vědy. Doubravník: Flow. ISBN 978-80-88123-10-1.

BEALE, Katy, 2011. Museums at Play: Games, Interaction and Learning. 1. vyd. United Kingdom: MuseumsETC. ISBN 978-1-907697-13-5.

BUCHTOVÁ, Michaela, 2012. Muzeum jako herní platforma: možnosti použití mobilních telefonů pro infromální učení. Muzeum: Muzejní a vlastivědná práce [online]. 50(2), 3-9. ISSN 18030386. Dostupné z: doi:10.2478/ mmvp-2018-0011

BUKAČOVÁ, Jana, Anna KOMÁRKOVÁ a František ŠEBEK, 2014. Muzejní výstavnictví: Učební texty nástavbového kurzu Školy muzejni propedeutiky Asociace muzeí a galerií České republiky. 1. vyd. Praha: Asociace muzeí a galerií České republiky. ISBN 978-80-86611-62-4.

BURIÁNKOVÁ, Michaela, Anna KOMÁRKOVÁ a František ŠEBEK, 2010. Úvod do muzejní praxe: Učební texty základního kurzu školy muzejní propedeutiky Asociace muzeí a galerií ČR. 1. vyd. Praha: Asociace muzeí a galerií České republiky. ISBN 978-80-86611-40-2.

CANTILLON, Zelmarie a Sarah BAKER, 2018-11-28. DIY Heritage Institutions as Third Places: Caring, Community and Wellbeing Among Volunteers at the Australian Jazz Museum. Leisure Sciences [online]. 2018, 1-19. ISSN 01490400. Dostupné z: doi:10.1080/01490400 .2018 .1518173

DERNIE, David, 2006. Exhibition Design. 1. vyd. London: Laurence King Publishing. ISBN 978-1-85669-430-8.

DOMAGK, Steffi, Ruth N. SCHWARTZ a Jan L. PLASS, 2010. Interactivity in multimedia learning: An integrated model. Computers in Human Behavior [online]. 26(5), 1024-1033. ISSN 07475632. Dostupné z: doi:10.1016/j.chb.2010. 03.003

DOWNE, Louise, 2011. Mobile Gaming - No Strings Attached? In: Museums at Play: Games, Interaction and Learning. 1. vyd. United Kingdom: MuseumsEtc, s. 576-583. ISBN 978-1-907697-13-5.

EKRT, Boris, 2017. Výstavní celek muzejního experimentária EperiMus - vývoj od konceptu Př́iběh planety země. Muzeum: Muzejní a vlastivědná práce [online]. 55(Zvláštní vydání), 24-27. ISSN 1803-0386. Dostupné z: doi:10.1515/mmvp-2017-0032

EVANS, Chris a Nicola J. GIBBONS, 2007. The interactivity effect in multimedia learning. Computers \& Education [online]. 49(4), 1147-1160. ISSN 03601315. Dostupné z: doi:10.1016/j.compedu. 2006.01.008

EVERBROECK, Christine Van, Sandra VERHULST a Sandrine PLACE, 2011. Let's Play Soldiers: Learning While Playing. In: Museums at Play: Games, Interaction and Learning. 1. vyd. United Kingdom: MuseumsEtc, s. 112-127. ISBN 978-1-907697-13-5.

FALK, John H. (2019, April). Emotions and museum-going. Presentation at the 3rd International Conference on Audience Research and Development, Connected Audience 2019 Berlin, Berlin, Germany. GOINS, Elisabeth, 2011. Museum Games and Narrative: The Way We Tell Stories with Objects. In: Museums at Play: Games, Interaction and Learning. 1. vyd. United Kingdom: MuseumsEtc, s. 500517. ISBN 978-1-907697-13-5. 
HORN, Michael S., Amartya BANERJEE, David BAR-EL a Izaiah Hakim WALLACE, 2020. Engaging families around museum exhibits: comparing tangible and multi-touch interfaces. In: IDC '20: Proceedings of the Interaction Design and Children Conference [online]. New York: Association for Computing Machinery, s. 556-566. ISBN 978-1-4503-7981-6. Dostupné z: doi:10.1145/3392063.3394443

JENKINS, Henry, 2008. Convergence Culture: Where Old and New Media Collide. 1. vyd. USA: NYU Press. ISBN 978-0814742952.

JONES, Katherine Burton, 2008. The Transformation of the Digital Museum. In: Museum Informatics: People, Information, and Technology in Museums. 1. vyd. New York: Routledge, s. 9-25. ISBN 0-415-80218-0.

KRYNEK, Ondřej, 2019. Národní muzeum otevřelo ve spojovací chodbě digitální expozici Momenty dějin. DesignMag. $c z$ [online]. 2020. ISSN 2464-6202. Dostupné z: http://www.designmag.cz/ umeni/85769-narodni-muzeum-otevrelo-ve-spojovaci-chodbe-digitalni-expozici-momenty-dejin.html

MANOVICH, Lev, 2018. Jazyk nových médii. 1. vyd. Praha: Univerzita Karlova. ISBN 978-80-246-2961-2.

MCKENNA-CRESS, Polly a Kamien Janet A., 2013. Creating Exhibitions: Collaboration in the Planning, Development, and Design of Innovative Experiences. 1. vyd. USA: Wiley. ISBN 978-1-118-30634-5.

Museum Definition, 2020. Museum Definition [online]. 2020. Paris: The International Council of Museums. Dostupné z: https://icom. museum/en/resources/standardsguidelines/museum-definition/

NEVINS, Elisabeth, 2018. The Past as a Brave Space: Reframing relevance. In: The State of Museums: Voices from the Field. 1. vyd. UK: MuseumsEtc, s. 1440. ISBN 978-1-912528-09-7.

PINCH, Trevor J. a Wiebe E. BIJKER, 2012. The Social Construction of Facts and Artifacts: Or How the
Sociology of Science and the Sociology of Technology Might Benefit Each Other. In: The Social Construction of Technological Systems: New Directions in the Sociology and History of Technology. Anniversary Edition. USA: MIT Press, s. 11-44. ISBN 978-0-262-51-760-7.

SAVENIJE, Geerte M. a Pieter de BRUIJN, 2017. Historical empathy in a museum: uniting contextualisation and emotional engagement. International Journal of Heritage Studies [online]. 23(9), 832-845. ISSN 1352-7258. Dostupné z: doi:10.108 0/13527258.2017.1339108

SEYČKOVÁ, Nina a Marco STELLA, 2014. Evoluce v Hrdličkově muzeu člověka. In: Muzeum a změna IV. Sborník z mezinárodní muzeologické konference. Praha: Asociace muzeí a galerií České republiky, s. 267-270. ISBN 978-80-86611-63-1. SCHALLER, David T., Minda BORUN, Steven ALLISON-BUNNELL a Margaret CHAMBERS, 2007. One Size Does Not Fit All: Learning Style, Play, and On-line Interactives. In: Museums and the Web 2007: Proceedings [online]. Toronto: Archives \& Museum Informatics. Dostupné z: http://www. archimuse.com/mw2007/papers/ schaller/schaller.html

SIMON, Nina, 2010. The Participatory Museum. 1. vyd. USA, California: Museum 2.0. ISBN 978-0-615-34650-2.

SMIRAGLIA, Christina a Lynn BAUM, 2018. Evalution and Audience Research in Museums: Past, Present, Future. In: The State of Museums: Voices from the Field. 1. vyd. United Kingdom: MuseumsEtc, s. 88-119. ISBN 978-1-912528-09-7.

SOARES, Bruno Brulon, ed., 2019. A History of Museology: Key authors of museological theory. Paris: International commitee for Museology - ICOFOM. ISBN 978-92-9012-456-6.

STEHLÍK, Michal, 2010. Nové trendy výstavnictví. In: Úvod do muzejní praxe: Učební texty základního kurzu Školy muzejní propedeutiky Asociace muzeí a galerii České republiky. 1. vyd. Praha: Asociace muzeí a galerií České republiky, s. 295302. ISBN 978-80-86611-40-2. 
ŠEBEK, František, 2014. Muzejní výstavnictví a jeho specifika. In: Muzejni výstavnictví: Učebni texty nástavbového kurzu Školy muzejní propedeutiky Asociace muzeí a galerií České republiky. 1. vyd. Praha: Asociace muzeí a galerií České republiky, s. 9-21. ISBN 978-80-86611-62-4.

ŠEBEK, František, 2014. Tvůrčí příprava muzejních expozic a výstav.
In: Muzejní výstavnictoí: Učební texty nástavbového kurzu Školy muzejní propedeutiky Asociace muzeí a galerii České republiky. 1. vyd. Praha: Asociace muzeí a galerií Ceské republiky, s. 22-43. ISBN 978-80-86611-62-4.

ŠOBÁŇOVÁ, Petra a Jolana LAŽOVÁ, 2016. Muzeum versus digitální éra. 1. vyd. Olomouc: Univerzita Palackého v Olomouci. ISBN 978-80-244-5023-0. 